\title{
Pottery use in the mining site of variscite Mines de Gavà (Barcelona, Spain) during the 4th millennium BC based on organic residue analysis
}

Tarifa-Mateo, N. ${ }^{\text {a,b }}$, Regert, M. c, Craig, O. E. ${ }^{\text {, }}$, Rosell-Melé, A. ${ }^{\text {e,f }}$, Clop, X. ${ }^{\text {a }, ~ S a n ̃ a, ~ M . ~}{ }^{\text {a }}$

${ }^{a}$ Universitat Autònoma de Barcelona, Department of Prehistory, Bellaterra, Spain

b Current address: Université de Strasbourg, CNRS, Institut de Chimie de Strasbourg UMR 7177, F-67000 Strasbourg, France

' Université Côte d’Azur, CNRS, CEPAM, France

d University of York, BioArch, York, UK

e Institut de Ciència i Tecnologia Ambientals (ICTA-UAB), Universitat Autònoma de Barcelona, Bellaterra, Catalonia, Spain

${ }^{\mathrm{f}}$ Institució Catalana de Recerca i Estudis Avançats (ICREA), Barcelona, Catalonia, Spain

Corresponding author: tarifa@unistra.fr

\begin{abstract}
Residue analysis in pottery usually concerns habitat or funerary sites. In this work, we have studied 21 vases from the Mines of Gavà (Barcelona, Spain) which constitute the oldest evidence of mining focused on variscite during the $\mathrm{IV}^{\text {th }}$ millennium BC. The main objectives are determining the degree of preservation of lipids in this context, identifying the natural substances exploited in the vessels and highlighting pottery use in the day-today mining work at this site, as well as establishing if some of the vessels are part of the grave goods from burials in the same mines. The results obtained by combining molecular and isotopic analyses showed that more than $70 \%$ of the containers investigated provided significant amounts of lipids. A wide diversity of organic substances processed comprising animal adipose fats, plants and beeswax was determined. Relationships found between the shape of the vessels and their content highlighted their role in the mining life. This work not only exposes one of the oldest evidences of the use of beeswax in pottery in the Iberian Peninsula, but also allows us to understand the management of resources in a very specialized archaeological site focused on mining activities.
\end{abstract}

Keywords: Neolithic - Postcardial - Pottery - GC-IRMS - Beeswax - Lipids - Iberian Peninsula 


\section{Introduction}

Variscite is a hydrated aluminium phosphate identified in the $19^{\text {th }}$ century by archaeologists and mineralogists. It is a green mineral that was used to make ornamental items from the $5^{\text {th }}$ millennium $\mathrm{BC}$ onwards, a custom that lasted until the $3^{\text {rd }}$ millennium BC. The archaeological sites in which variscite artefacts have been discovered are mainly located in Western Europe: the Iberian Peninsula, Southern and Western France (Querré et al., 2015; 2019).

The site of the Mines of Gavà not only allows documenting the occupation of the Neolithic populations throughout the $4^{\text {th }}$ millennium cal BC, but also constitutes a singular site. The data obtained from the archaeological work carried out from the 1970s onwards describe a complex network of underground galleries excavated in the shales in the area of Les Ferreres, Can Tintorer and Rocabruna, dedicated to the exploitation of variscite and other minerals, such as turquoise, in order to produce ornamentation objects (Blasco et al., 2000). The 110 mines documented in the site constitute the first large scale Neolithic underground mining operation found in the Iberian Peninsula. In the European context, it is the only site with clear evidence of large-scale exploitation of variscite (Blasco et al., 2000).

After the end of the Early Neolithic in the northeast of the Iberian Peninsula from 4200 BC changes in different social, economic and cultural aspects are documented. One of the characteristic cultural changes is the substitution of the impressed cardial decorations by the impressions and incisions with other instruments and by the notable increase of smooth cords (Bosch and Estrada, 1993). In this context, different ceramic vessels with characteristics typical of the Molinot-type Postcardial style were discovered inside the mines (Calvo, 2019). Some of them correspond to wasted material left after exploitation of the mine and, therefore, come from a unique context such as the workspace (Bosch and Estrada, 1998; Bosch et al., 1994). Other vessels are part of the grave goods of the burials that were carried out in some mines after their exploitation (Donoso, 1998). However, behind the Mines of Gavà there is a wider problem of whether the site responds to a specialized workplace or whether it is also part of a habitat of the human group that exploited the environment. The need for multidisciplinary studies will help to better understand the mechanism in which Mines de Gavà was part. 
In the last 50 years, analytical techniques have been developed to study organic residues in pottery that have allowed to gain a better understanding of the use and functionality of archaeological materials, and a better insight in the daily life of the human groups that produced and used them. Such organic residues are usually adsorbed in archaeological ceramic vessels and are present at low concentrations. Their characterization is typically undertaken by means of gas chromatography - mass spectrometry (GC-MS).

In the recent years, application of these analytical techniques has favoured the detection of organic markers indicative of pottery use and product consumption since the beginning of the Neolithic period. The products detected absorbed in the ceramic containers used during the Neolithic period are animal fats (Ethier et al., 2017; Gillis et al., 2017; Mukherjee et al., 2008; Šoberl et al., 2014), dairy products (Copley et al. 2005a; Cramp et al., 2014; Cubas et al., 2020; Dunne et al., 2018; Evershed et al., 2008b; Isaksson and Hallgren, 2012; Ogrinc et al., 2012; Regert et al., 1999; Roffet-Salque et al., 2012; Spiteri et al., 2016; Tarifa-Mateo et al., 2019; Whelton et al., 2018), aquatic resources (Cramp et al., 2019; Evershed et al., 2008a), vegetable resources (Dunne et al., 2018; Evershed et al., 2008b; Hammann and Cramp, 2018; Matlova et al., 2017) and beeswax (Drieu et al., 2020; Drieu et al., in press; Regert et al., 2001b; Roffet-Salque et al., 2015). While animal fats are frequently identified in pottery, other substances, such as beeswax, are surprisingly poorly documented in regions, such as the Iberian Peninsula, despite being quite common in Europe during Neolithic (Roffet-Salque et al., 2015).

In this work, twenty-one vases from the archaeological site of Mines de Gavà were analyzed in order to bring new data on the use and consumption of different products inside pottery during the Postcardial Neolithic period in the Iberian Peninsula (3800-3300 cal BC).

\section{Site and materials}

The prehistoric site of Mines of Gavà was a mining centre for the production and distribution of variscite. It is located in the council of Gavà, in the northeast of the Iberian Peninsula (Figure 1). For the time being, 110 mines have been documented in an area of about $245 \mathrm{~m}^{2}$ with an altitude ranging between 33 and $94 \mathrm{~m}$ a.s.l. Although today the coastline is quite distant, during the Neolithic, the sea was probably located closer, at ca. $2 \mathrm{~km}$ from the site (Bosch and Estrada, 1994). 


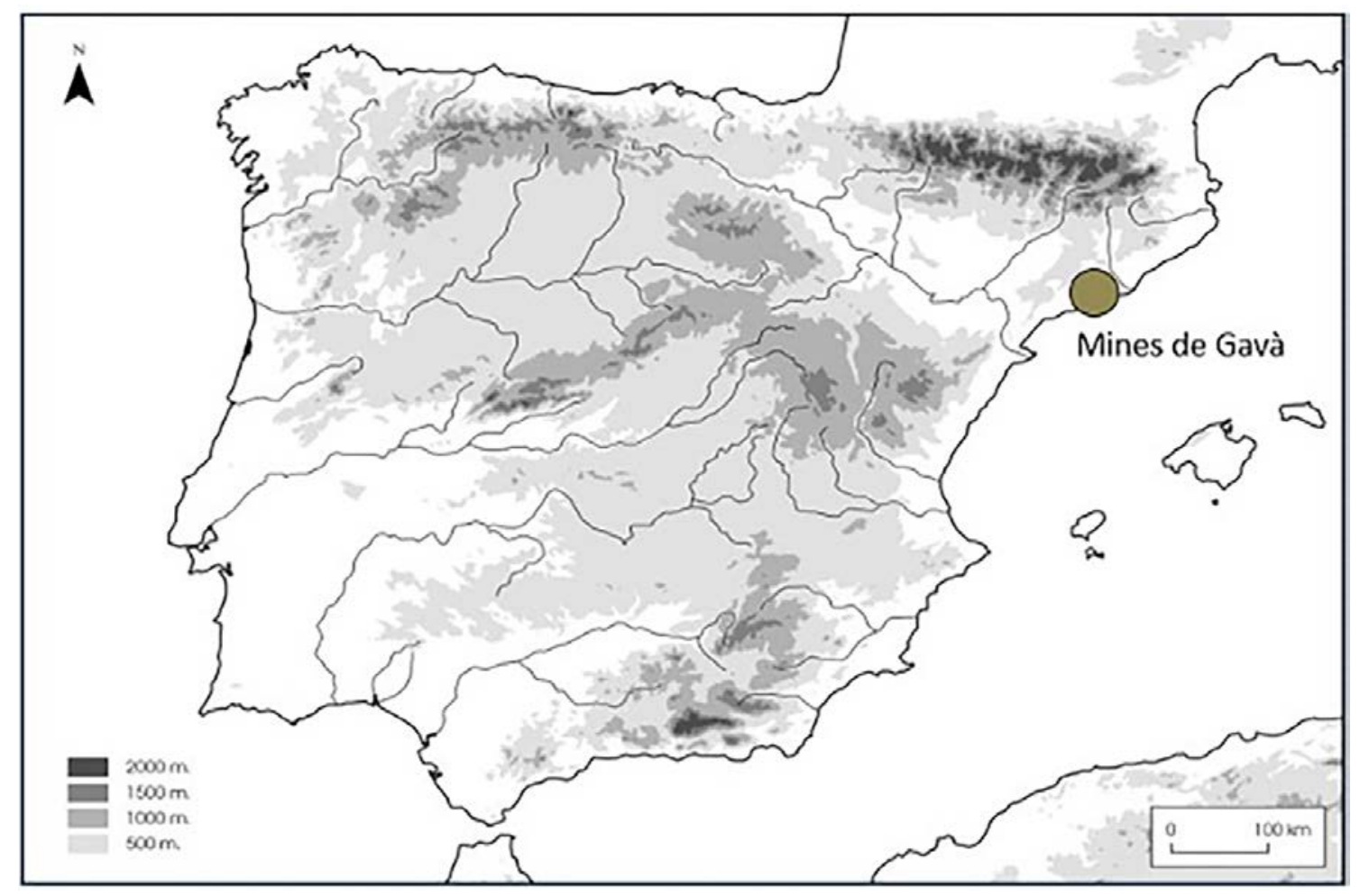

Figure 1. Geographical situation of the Mines de Gavà site (source: Trabajos de Prehistoria, http://tp.revistas.csic.es/index.php/tp/about/submissions).

The dating of charcoal and bone remains from different mines shows that the exploitation phases of the Mines de Gavà began in the Postcardial Neolithic and ended in the Middle Neolithic (4500-3500 cal BC) (Table 1 SI; Bordas et al., 2009; Bosch, 2010). The mines present different morphologies of the mining structures. Wells with isolated galleries have been documented together with other mines comprising dense networks of galleries and chambers at different levels of depth (Borrell, 2009; Figure 2). Geological studies show that underground mining activities required a complex knowledge of exploitation strategies (Borrell and Bosch, 2012). Mines 8, 9, 28, 83 and 84 were found to have been reused as burial sites (Villalba et al., 1986). The funerary use for these mining structures has been dated to the early Middle Neolithic (Table $1 \mathrm{SI}$ ). The burials of one or two individuals were documented accompanied by grave goods, consisting of variscite objects, ceramic vessels, bone and lithic industry (Borrell and Bosch, 2009; Borrell et al., 2015). The burial spaces are located in the internal parts of these mines, which were no longer being exploited and were conditioned for this new use. The closure of the access to the mine is made from large blocks at the entrance and a series of medium-sized slabs and sediment inside (Borrell and Bosch, 2009). 
Although no evidence of settlement has been documented, it has been proposed that one or more population groups were established in ephemeral constructions located in the immediate surroundings of the mining exploitation (Bosch and Santacana, 2009). In this respect, constructive elements related to these domestic spaces have been found, such as adobe materials, suggest a stable settlement (García-Atiénzar, 2009).
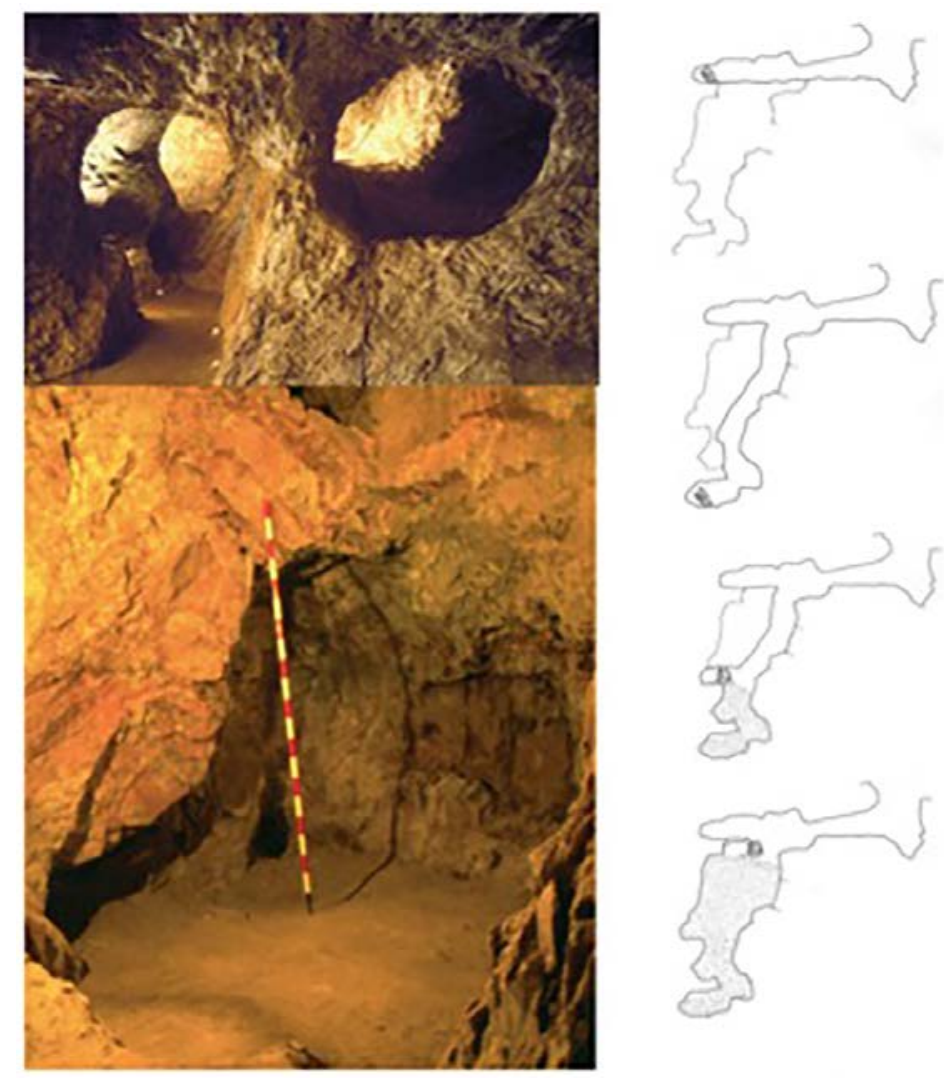

Figure 2. Mining structures from Gavà and refilling process (Museu de Gavà, Bosch et al., 2019).

A possible specialization of the Neolithic communities of Gavà in mining has been considered. Some tools related to the practice of mining work have been recovered, such as axes, adzes, picks and maces (Donoso, 1998). On the other hand, there is evidence suggesting other economic practices. There is little evidence of farming during the early stages of mining (Bosch and Estrada, 1994). We must, however, bear in mind that, given their specificity, remains of consumption are more present in the archaeological record than evidence of production. An indication for these activities directed to the subsistence of the group could be found in the archaeobotanical studies (Bosch and Estrada, 1994; Ros, 1994). According to these, the configuration of the local landscape of the postcardial Mines de Gavà was constituted by weeds and bushes. Such an environment was interpreted as the result of the anthropic degradation of the forests for the intensification 
of the agricultural practices and/or cattle farming (Bosch and Estrada, 1994). During the Middle Neolithic, the agricultural exploitation was intensified as evidenced by the occurrence of carpological remains of domestic species. Crop species were represented by cereals, among which barley (Hordeum vulgare) was an important contributor, while the proportion of wheat grains was lower (Triticum dicoccum and Triticum aestivum). Leguminous plants (Vicia sp.) were represented only to a lesser extent (Buxó, 2007). In addition, the possible secondary use of abandoned mines as a food storage site, where carpological remains have been documented in clay containers (Bosch, 1994). Other economic activities have also been documented in the mines of Gavà, such as animal husbandry involving the four main domestic species: cattle (Bos taurus), sheep (Ovis aries), goat (Capra hircus) and pig (Sus domesticus). This livestock activity would have been mainly oriented to the production of meat (Estévez 1986; Saña 1993). Hunting would be minimally represented with remains of red deer Cervus elephus), fox (Vulpes vulpes), wild boar (Sus scrofa), rabbit (Oryctolagus cuniculus) and mediterranean seal (Monachus monachus). The representation or presence of these faunal species is variable depending on the use and speciality of each mine.

The ceramic remains recovered from the different mines generally appear as fillings of exhausted mines, although vessels associated with the grave goods identified inside the mines have also been documented. Supplementary data shows the characteristics of the selected vessels and their level of fragmentation, as well as the location of the extracted sample. Most of the vessels are fragmented, with some exceptions. From the reconstruction of the profiles of the different ceramic vessels carried out for some of the mines studied, vases were identified with gripping and suspension elements, with incised and impressed decorations (Bosch and Estrada, 1993; Bosch et al., 1994; Villalba et al., 1986). However, from the Middle Neolithic onwards, we find little decorated vases with a polished surface treatment. In this respect, we find that the ceramic ensemble of Mines de Gavà is related to other ensembles of the Middle Neolithic in Catalonia and corresponds to an evolution of the types of the facies Montboló and Molinot. The typology and dimensions of these ceramics are very variable. With a high-quality finishing, the colours tend to be dark as a result of firing in a reducing environment without many decorations. Simple profiles predominate, with globular and hemispherical trends, open and closed, as well as more or less marked fairings (Calvo, 2019). In particular, sample MIG18 has a unique shape and was found in a funerary context inside 
the mine. This type of vase appears for the first time, according to the data currently available, in the context of the so-called "Cultura di vasi a bocca quadrata" (VBQ) developed in northern Italy during the $5^{\text {th }}$ millennium cal BC (Bagolini and Pedrotti, 1998; Bazzanella, 1999). Petrographic analyses of these vessels allowed to determine that the vessels of this type found outside the Italic Peninsula, as in the cases of the Iberian Peninsula, are local productions, which would imply that the concept would circulate and not the vessels (Clop and Álvarez, 2009; Cubas et al., 2017).

The study of the organic residues from Mines de Gavà pottery assemblage is based on the analysis of 21 samples from a total corpus of vessels recovered from different mines (Table 1). The mines are built on the basis of wells with the intention of extracting variscite. The aim of the sampling of vessels from different mines was to determine the possible differentiated use of the vessels according to their chronology, morphology, location and context. Thus, we selected vessels from mines 6, 7, 41, 68, 89 and 90 that were found together with mining materials (remains of variscite, lithic tools, etc.), and vessels from mines 8, 83 and 84 that were amortized for funerary use. Small cavities for lighting were also identified in mine 84.

Whenever possible, the sampled vessels corresponded to restored or partially restored forms, in order to know their morphotypology and to be able to define their metric aspects (mouth opening, volume, wall thickness, etc.) (See supplementary material). In this way, the selected vessels are intended to represent the different typologies. All the containers were assessed globally and the morphometric categories were grouped in order to be able to make a representative selection of all of them. In these categories, the volume, the opening of the mouth, the presence of handles, the thickness of the walls and the general morphological characteristics (presence of necks, type of bases...) were studied. No traces of visible residues, such as foodcrusts, have been observed on the surfaces, nor are there any obvious signs of use. The physical properties of the fired clay of each vessel were also taken into account, given that the degree of porosity of the surface has a significant impact on absorption, as well as firing temperature and surface treatments (CorreaAscencio and Evershed, 2014, Evershed, 2008, Rice, 2015, Stern et al., 2000). For this reason, priority has been given to the internal surfaces of vases corresponding to the lips and the bases of ceramics. 
Table 1. Selection of analyzed pots from Mines de Gavà. (see at the end of the paper)

\section{Methods}

\subsection{Lipid extraction}

For lipid extraction of potsherds, the surface of a sub-sample of the archaeological potsherds was cleaned with a manual modelling drill to remove exogenous lipids (Stacey, 2009), and subsequently $2 \mathrm{~g}$ of fine powder. In a glass tube, a volume of $20 \mu \mathrm{l}$ of a cyclohexane solution containing an internal standard (n-tetratriacontane, Sigma; 24.98 $\mathrm{ng} / \mu \mathrm{L}$ ) was added to the powder. Lipids were extracted by ultrasonication (twice $\mathrm{x} 15$ $\mathrm{min}$ ) using a chloroform/methanol mixture (2:1 v/v, $10 \mathrm{~mL})$. The total lipid extract (TLE) was recovered after centrifugation (20 min, $3000 \mathrm{rpm}$ ) of the mixture, and the solvent was removed under a gentle nitrogen stream with heating $\left(42^{\circ} \mathrm{C}\right)$. The TLE was dissolved in a mixture of chloroform/methanol (2:1 v/v) and $200 \mu \mathrm{l}$ aliquots were recovered. After removal of the solvent, the aliquots were derivatized with $50 \mu \mathrm{L}$ of $\mathrm{N}, \mathrm{O}-$ bis(timethylsilyl)tetrafluroacetamide (BSTFA, Sigma) at $70{ }^{\circ} \mathrm{C}$ for $30 \mathrm{~min}$. After evaporation of the excess of BSTFA, the derivatized samples were re-dissolved into cyclohexane prior to their analysis by HT GC-FID (High-Temperature Gas Chromatography with Flame-Ionization Detection), and HT GC-MS (High-Temperature Gas Chromatography-Mass Spectrometry). The TLE calculation is done after HT GCFID injection by comparing the IS with an external standard (20 $\mu$ l of a cyclohexane solution with n-tetratriacontane, Sigma; $24.98 \mathrm{ng} / \mu \mathrm{L})$. Thus, it was calculated that the lipid loss during extraction was comparable for all samples, between $8 \%$ and $10 \%$.

Fatty acid methyl ester derivatives (FAMEs) of an aliquot of the TLE (100 $\mu \mathrm{l})$ were prepared by adding $4 \mathrm{~mL}$ of a $\mathrm{H}_{2} \mathrm{SO}_{4}$-methanol solution (2\% v/v) at $70{ }^{\circ} \mathrm{C}$ for $4 \mathrm{~h}$. After cooling, water $(3 \mathrm{~mL})$ was added and the lipids were extracted with cyclohexane (3 times x $2 \mathrm{~mL}$ ). The solvent was evaporated under nitrogen in readiness for GC- isotopic ratio mass spectrometry (IRMS) analysis.

\subsection{GC-FID and GC-MS analyses}

HT GC-FID analyses were performed on an Agilent 7890A gas chromatograph using a DB5-HT column (15m length x 0.32mm internal diameter x $1 \mu \mathrm{m}$ film thickness). The oven temperature was programmed to be held at $50{ }^{\circ} \mathrm{C}$ for $1 \mathrm{~min}$, then increased at 10 ${ }^{\circ} \mathrm{C} / \mathrm{min}$ to $350{ }^{\circ} \mathrm{C}$ and set at $350{ }^{\circ} \mathrm{C}$ for $10 \mathrm{~min}$. The FID temperature was set at $350{ }^{\circ} \mathrm{C}$. 
Helium was the carrier gas. Data were acquired and processed using Agilent Chemstation software.

The HT GC-MS analyses were carried out using a Shimadzu GC2010PLUS series gas chromatograph coupled with a Shimadzu QP2010ULTRA quadrupole massspectrometer. Injection was performed through a split/splitless injector used in the splitless mode at $300^{\circ} \mathrm{C}$. A DB-5HT column (15 m length x $0.32 \mathrm{~mm}$ internal diameter $\mathrm{x} 1 \mu \mathrm{m}$ film thickness) was used. The oven temperature was programmed to be held at 50 ${ }^{\circ} \mathrm{C}$ for $1 \mathrm{~min}$, then increased at a rate of $15^{\circ} \mathrm{C} / \mathrm{min}$ to $100{ }^{\circ} \mathrm{C}$, at $10^{\circ} \mathrm{C} / \mathrm{min}$ to $240{ }^{\circ} \mathrm{C}$, at $20{ }^{\circ} \mathrm{C} / \mathrm{min}$ to $380{ }^{\circ} \mathrm{C}$ and held at $380{ }^{\circ} \mathrm{C}$ for $7 \mathrm{~min}$. Helium was the carrier gas, held at a constant flow of $88 \mathrm{~cm} / \mathrm{s}$. The analyses were carried out in the electron ionization mode at $70 \mathrm{eV}$, the temperature of the source being fixed at $200{ }^{\circ} \mathrm{C}$. Mass spectra were acquired in full scan mode, from $\mathrm{m} / \mathrm{z} 50$ to 950 u.m.a. Data were acquired and processed by using Shimadzu GC-MS Solution (version 2.70) software. Identification of the peaks was based on relative retention times in GC and mass spectra of commercial molecular standards (Sigma) and by comparison with NIST mass spectral library.

Finally, when fatty acids were identified ( $\mathrm{C}_{18: 0}$ and $\left.\mathrm{C}_{16: 0}\right)$, a third analysis was performed using a IRMS mass spectrometer (Delta V, ThermoFisher Scientific) connected to a gas chromatograph (Trace GC, ThermoFisher Scientific) via a combustion interface. The GC was fitted with a DB-5 MS capillary column (60 m length, $0.25 \mathrm{~mm}$ internal diameter, $0.25 \mu \mathrm{m}$ film thickness). The injector temperature was set at $310{ }^{\circ} \mathrm{C}$. The oven was initially held at $80{ }^{\circ} \mathrm{C}$ for $1 \mathrm{~min}$, then increased at $30^{\circ} \mathrm{C} / \mathrm{min}$ to $120{ }^{\circ} \mathrm{C}$, and finally increased to $320^{\circ} \mathrm{C}$ at $6^{\circ} \mathrm{C} / \mathrm{min}$ and held for $21 \mathrm{~min}$ at $320^{\circ} \mathrm{C}$. Helium was used as carrier gas. The temperature of the combustion reactor was set at $940{ }^{\circ} \mathrm{C}$. The samples were analyzed in triplicate.

The carbon isotope ratios are expressed relative to the standard reference material $v \mathrm{PDB}$, $\delta^{13} \mathrm{C} \%=\left[\mathrm{R}_{\text {sample }}-\mathrm{R}_{\text {standard }}\right] / \mathrm{R}_{\text {standard. }}$. The $\delta^{13} \mathrm{C}$ values were corrected for the carbon atom(s) of the methyl/silyl group added during methylation/silylation of the fatty acids using the following equation: $\left.\delta^{13} \mathrm{C}_{\mathrm{FA}}=\left((\mathrm{n}+1) \times \delta^{13} \mathrm{C}_{\mathrm{FAME}}\right)-\delta^{13} \mathrm{C}_{\mathrm{MeOH}}\right) / n$ (for the methylation process) and $\left.\delta^{13} \mathrm{C}_{\mathrm{FA}}=\left((\mathrm{n}+3) \times \delta^{13} \mathrm{C}_{\mathrm{FATMS}}\right)-3 \times \delta^{13} \mathrm{C}_{\mathrm{TMS}}\right) / n$ (for the silylation process), where $\delta^{13} \mathrm{C}_{\mathrm{FA}}$ is the corrected value for the fatty acid, $n$ is the carbon chain length. Both correction factors were obtained by derivatising a known $\delta^{13} \mathrm{C}_{\mathrm{FA}}$ value with the derivatisating agent. 
The isotopic results were compared with those obtained on the modern reference fats already published in the literature (see Supplementary Table 2). Among the groups of modern reference values there are 13 values for domestic pigs (Evershed et al., 1997; Colonese et al., 2017; Copley et al., 2003, Spiteri, 2012), 38 samples of domestic ruminant adipose fats (ox, cow, goat, sheep; Carrer et al., 2016; Copley et al., 2003; Dudd, 1999; Dunne et al., 2012; Evershed et al., 1997; Gregg et al., 2009; Spiteri, 2012), 54 values obtained from dairy products (Carrer et al., 2016; Copley et al., 2003; Craig et al., 2012; Dudd, 1999; Dunne et al., 2012; Gregg et al., 2009; Outram et al., 2009; Spiteri, 2012) and 43 from marine resources (fish, moluscs and seals; Craig et al., 2011; 2013; Dudd, 1999; Horiuchi et al., 2015; Lucquin et al., 2016; Spiteri, 2012).

\subsection{Pottery volume calculation}

Measuring the capacity of a container is not always possible, especially because intact archaeological vases are quite rare, and the fragments found do not always make it possible to reconstruct the vase geometry. There are different methods to calculate the volume of vessels. Despite the recent digital revolution and widespread technological innovations, which method is the most reliable and efficient is still open to debate (e.g. Rodriguez and Hastorf, 2013). Three methods are often used to calculate the volume of archaeological pottery vessels, reconstructed or fragmented: truncated cones (Senior and Birnie, 1995), three-dimensional from a single radial section (Karasik and Smilanski, 2006; Sánchez and Cerdeño, 2014; SopenaVicién, 2006; Velasco and Celdrán, 2019; Zapassky et al., 2006) or from several radial sections (Portillo and Sanz, 2020). In order to calculate the volume of vessels of different shapes and sizes, the following process was followed: initially n-measurements were taken (according to the morphometry of the vessel, between 10 and 24 segments) of the distance between the axis of symmetry of the vessel and its outer wall (R); then the height was also measured (distance from point A to point B). Using these points, the curve of the vessel profile can be calculated; using a polynomial of degree $p(p=3$ to 6$)$ approximates the function: $f(r)$; the degree of the polynomial function can vary to get a better approximation $(\mathrm{R} 2 \approx 1)$. Once the function $\mathrm{f}(\mathrm{r})$ is obtained, by means of the complete revolution $(\Theta=2 \pi \mathrm{rad})$ of the area between the $f(r)$ and the axis of symmetry, the value of the volume of the vessel can be obtained (cylindrical coordinates were used for this calculation; Figure 3). 
Computing the volume of archaeological vessels from several radial section gives an accurate approximation, given that archaeological pottery usually has deformations (Portillo and Sanz, 2020). Nevertheless, it is demonstrated that three-dimensional with a single radial section method is accurate enough to be used in prehistoric handmade pottery (the percentage deviation from the actual volume does not exceed 10\% in large vessels in both methods; Velasco and Celdrán, 2019).

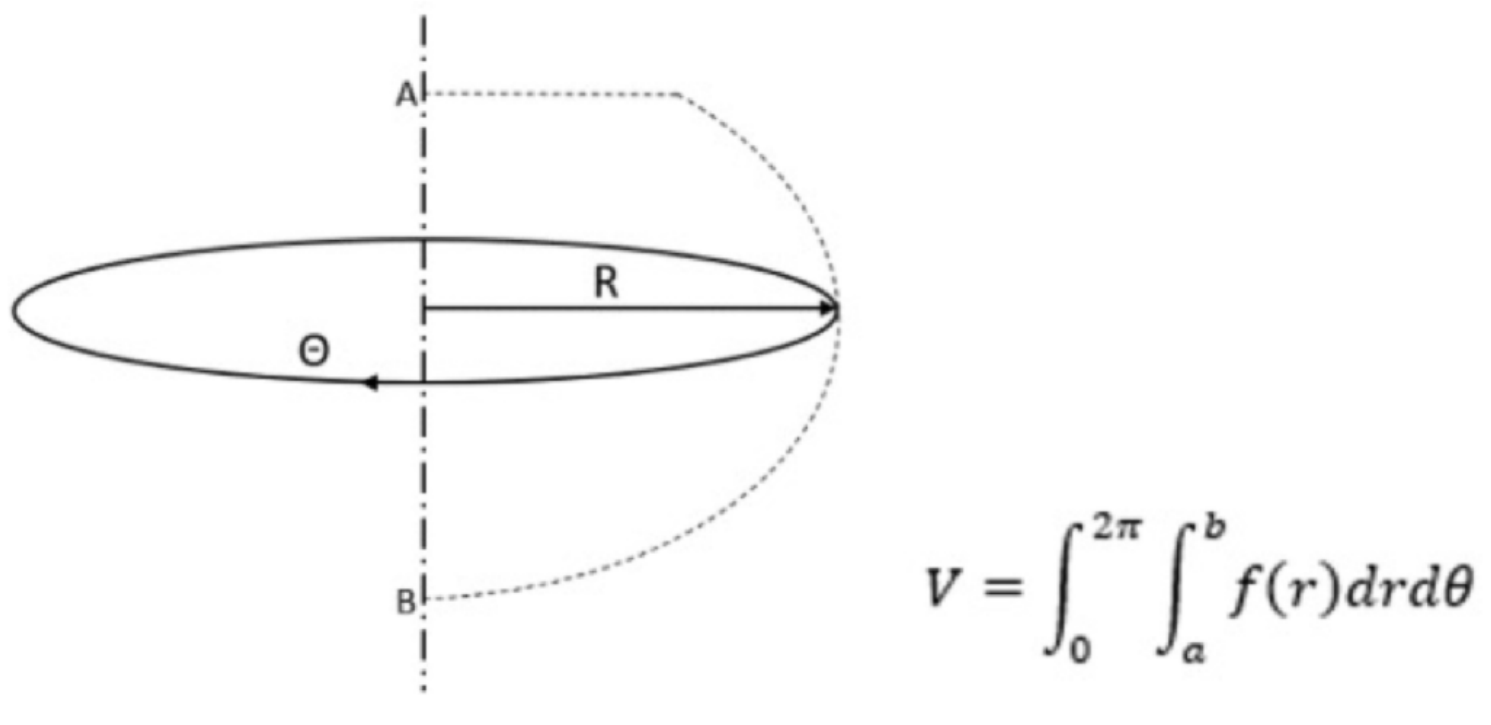

Figure 3. Variables drawing (left) and volume calculation formula (right). 


\section{Results}

\subsection{Organic residue analysis}

Fifteen of the 21 sherds analyzed (71.4\%) contained appreciable amount of lipids (i.e. $>5 \mu \mathrm{g} \cdot \mathrm{g}^{-1}$; Evershed, 2008) (Table 2). The TLE were dominated by saturated fatty acids, mainly palmitic $\left(\mathrm{C}_{16: 0}\right)$ and stearic $\left(\mathrm{C}_{18: 0}\right)$ acid, with sometimes the occurrence of monoacylglycerides (MAGs), diacylglycerides (DAGs) and triacylglycerides (TAGs) and animal and/or plant sterols.

Table 2. Organic residues analysis from Mines de Gavà. Abbreviations stand for: TLE, total lipid extract; PS, palmitic-stearic ratio; FA, fatty acids; MAG, monoacylglycerides; DAG, diacylglycerides; TAG, triacylglycerides. See at the end of the paper.

\subsubsection{Animal fats}

In Mines de Gavà, fatty acid distributions dominated by the $\mathrm{C}_{16: 0}$ and $\mathrm{C}_{18: 0}$ homologues were identified in 14 vases (67 \%). The good preservation of organic matter has allowed the conservation of MAGs, DAGs and, in some cases, TAGs (MIG09, MIG14, MIG16, MIG21 and MIG22). Triacylglicerides (TAGs) are the main components of natural fats and oils (Christie 1989). The position of each of the fatty acids that make up the TAG, as well as their nature (chain length, number and position of unsaturations) are the result of different enzymatic mechanisms and are highly variable according to the natural origin of the fat. In order to identify TAGs and trace the natural origin of a fat, it is necessary to know the composition of the fatty acids, but also their distribution across the glycerol skeleton.

The distribution and concentration of carbon numbers of TAGs allows us to get closer to the origin of the fat. Thus, classical ruminant fat profiles are distributed between $\mathrm{T}_{46}$ and $\mathrm{T}_{54}$, with $\mathrm{T}_{50}$ and $\mathrm{T}_{52}$ predominant (Dudd et al. 1999, Mukherjee et al. 2007, Regert et al. 1999). Dairy products are characterized by a wider distribution, between $T_{40}$ and $T_{54}$, with special concentrations of $\mathrm{T}_{50}$ and $\mathrm{T}_{52}$ (Dudd and Evershed, 1998, Mirabaud et al., 2007). Non-ruminant fat profiles are distributed between $\mathrm{T}_{46}$ and $\mathrm{T}_{54}$, with $\mathrm{T}_{52}$ being the most dominant (Dudd et al. 1999). Finally, plant oil profiles are dominated by $\mathrm{T}_{54}$ (Copley et al., 2005b; León-Camacho et al., 2004; Leskinen et al., 2007). 
The presence of TAGs, together with other sterols of animal origin (cholesterol in MIG13 sample), prevents the interpretation of a single animal origin for free fatty acids (Papakosta et al., 2019): the “mixed” patterns of triacyglyceride distribution do not clearly identify the original source of the fat (Figure 4), possibly resulting from multiple episodes of use/mixed foodstuffs (Muckherjee et al., 2008).

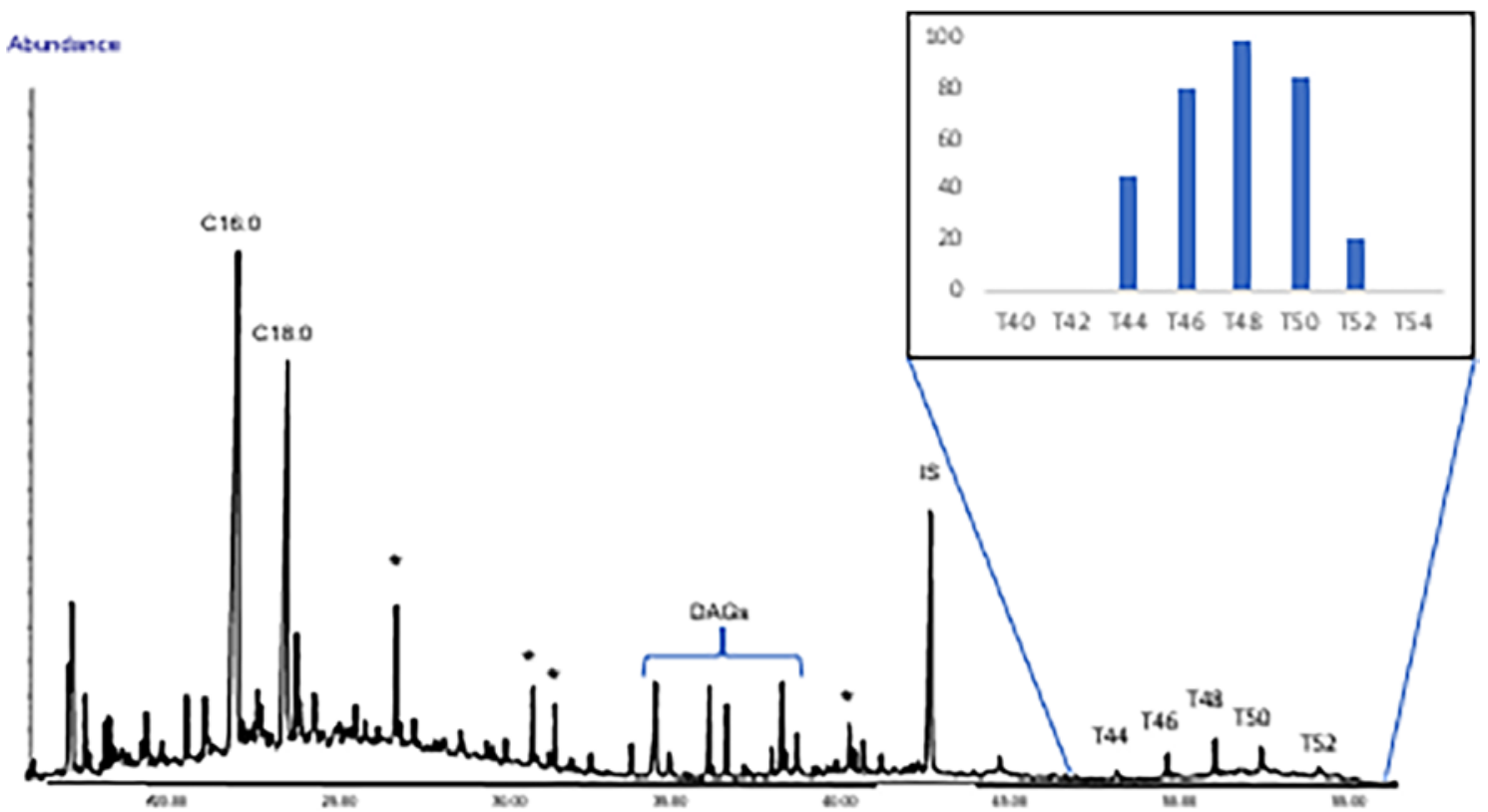

Toma-

Figure 4. Partial gas chromatogram of total lipid extract of sample MIG21; $\mathrm{C}_{\mathrm{n}: 0}$ : saturated fatty acids with $n$ carbon atoms; DAG: diacylclyceride; TAG: triacylglyceride; IS: internal standard, $\mathrm{C}_{34}$ n-tetratricontane; *: contaminants (phthalates). (Inset - Typical distribution of triacylglycerides in total lipid extracts from Mines de Gavà pottery vessels). 
The ratio of palmitic to stearic acid (P/S) is argued to provide insights into the sources of fatty acids (Romanus et al., 2007). Nevertheless, these data have to be considered very cautiously because degraded animal fats could have modified P/S ratio due to alteration processes or because of the mixture of different substances (Regert, 2011).

The range of most of the P/S ratio values in the samples analyzed is between 0.9 and 1.6, with an average of 1.4. These values make a reliable interpretation of these indicators difficult in comparison with the ratios obtained from the reference values in different previous works (Colonese et al., 2017; Copley et al., 2003; Courel et al. 2020; Dudd, 1999; Spiteri, 2012) Furthermore, no clear correlation has been found between these data and the $\delta^{13} \mathrm{C}$ isotopic values obtained for palmitic and stearic acid. Only sample MIG21 stands out from the others (4.69 P/S ratio), indicating commodities rich in palmitic acid, which could be due to the presence of plants or fish (Copley et al., 2001).

Fatty acids extracted from the vessels were analyzed by GC-IRMS following derivatisation to their FAMEs. The $\delta^{13} \mathrm{C}$ values allow the biological origin of the identified lipids to be broadly determined. As can be seen in Figure 5, the values of the fatty acids identified in samples MIG09, MIG11, MIG14 and MIG20 are consistent with those corresponding to modern non-ruminant reference values while samples MIG12, MIG17, MIG19, MIG22 and MIG28 show isotopic values consistent with reference values for fatty acids from domestic ruminants such as cows, goats and sheep (Figure 5). The $\Delta^{13} \mathrm{C}$ values of the fatty acids from MIG10, MIG13, MIG16 and MIG21 samples on the borderline of the ranges of values determined for non-ruminant and ruminant adipose fat may indicate a mixed origin. The presence of ${ }^{13} \mathrm{C}$ enriched values of non-ruminant fats raises the possibility of marine resources in the ceramic containers, as they are comparable with the measurements of authentic marine oils (Pääkönen et al., 2018). However, it has been noted that $\delta^{13} \mathrm{C}$ values of terrestrial animal fats from southern Europe are likely to be higher compared to those from northern Europe (Spiteri, 2012) and this is supported by more recent analysis of animal fats from the Mediterranean (Breu, 2019; Tarifa-Mateo, 2019). Therefore, we suggest that the non-ruminant values in the Mines de Gavà are from domestic pigs. 


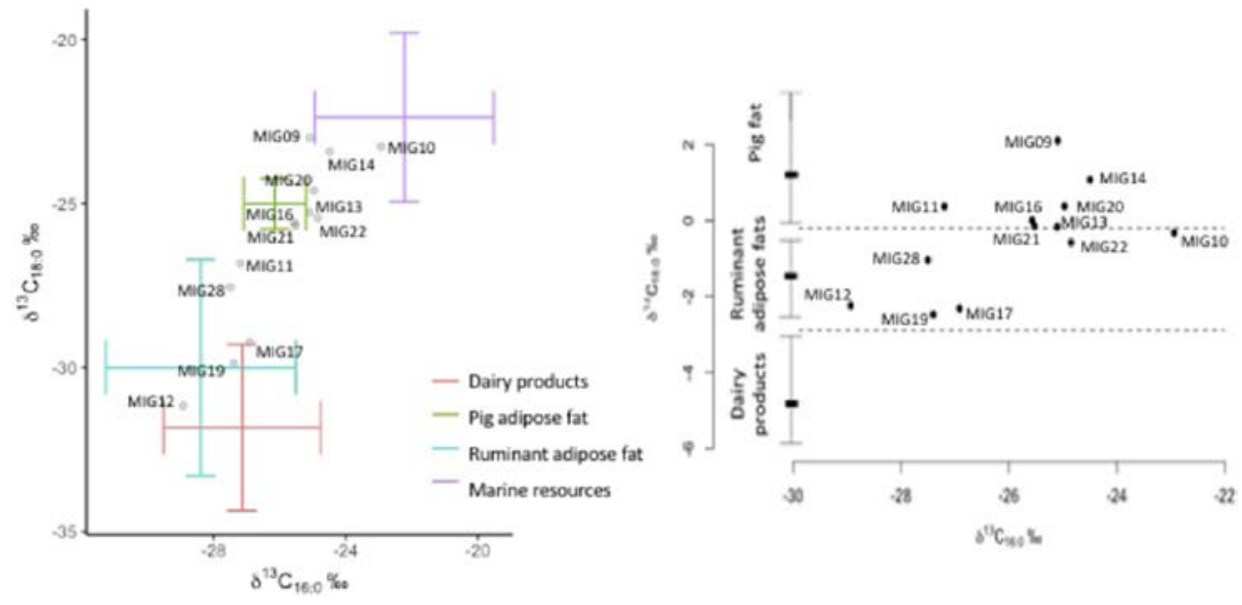

Figure 5. $\delta^{13} \mathrm{C}$ values of $\mathrm{C}_{16: 0}$ and $\mathrm{C}_{18: 0} \mathrm{n}$-alkanoic acids (a) and $\delta^{13} \mathrm{C}$ values of $\mathrm{C}_{16: 0}$ and $\Delta^{13} \mathrm{C}\left(\delta^{13} \mathrm{C}\right.$ $\mathrm{C}_{18: 0}-\delta^{13} \mathrm{C}_{16: 0} \mathrm{n}$-alkanoic acids) (b) obtained from Mines de Gavà site. The $68 \%$ confidence ellipses are based on modern reference fats extracted from the literature (See Supplementary Table 2).

Animal remains have been found in the mines. They may correspond to anthropogenic deposits originating from a period when the mine was no longer functioning, or they might correspond to natural deposits in the case of wild animals remains such as rabbits or amphibians.

No biomarkers of aquatic resources, such as isoprenoids fatty acids (Copley et al., 2004; Craig et al., 2007; Hansel et al., 2004), were detected. However, a number of malacological remains from marine/brackish species, including Glycymeris sp., have been documented (Bosch and Estrada, 1998), together with fish remains characteristic of estuary areas and sandy bottoms (e.g., Sparus aurata and Myliobatis aquila; Estevez, 1989), and phocid remains (Bosch and Estrada, 1998). This evidence indicates the practice of collecting aquatic sources from land but these activities could be developed outside the use of ceramics.

\subsubsection{Plant lipids}

Considering the $\mathrm{P} / \mathrm{S}$ ratio, the high abundance of $\mathrm{C}_{18: 0}$ in some samples ( $\mathrm{P} / \mathrm{S}$ ratio $>1,3$ in MIG09, MIG11, MIG12, MIG21 samples) suggests a plant input (Copley et al., 2001; Regert, 2011; Romanus et al., 2007). Unsaturated fatty acids $\left(\mathrm{C}_{18: 1}\right)$ and plant sterols (mainly $\beta$-sitosterol and stigmasterol) were detected in some samples (MIG11, MIG13, MIG16, MIG21, MIG22, MIG28 samples), indicating plant input or a mixture of lipids from meat and plants inside the vases (Dunne et al., 2016). Nevertheless, absorbed residues originating from plant oils tend to be very low and often masked by fattier products, and are therefore difficult to identify securely. 
The presence of plants in the culinary practices that can be defined in the Mines de Gavà site leads us to consider the exploitation of these resources, whether they are the result of harvesting or agricultural activities.

\subsubsection{Beeswax}

In two samples from Mines de Gavà (MIG18 and MIG25) biomarkers, characteristic of beeswax, were present. These include even-numbered long-chain wax esters- (W40W52) derived from palmitic acid $\left(\mathrm{C}_{16: 0}\right)$ esterified to long-chain alcohols (from AL24 to AL36) (Evershed et al., 1997; Garnier et al., 2002; Namdar et al., 2009; Regert et al., 2001a; 2003; Roffet-Salque et al., 2015; Figure 6).

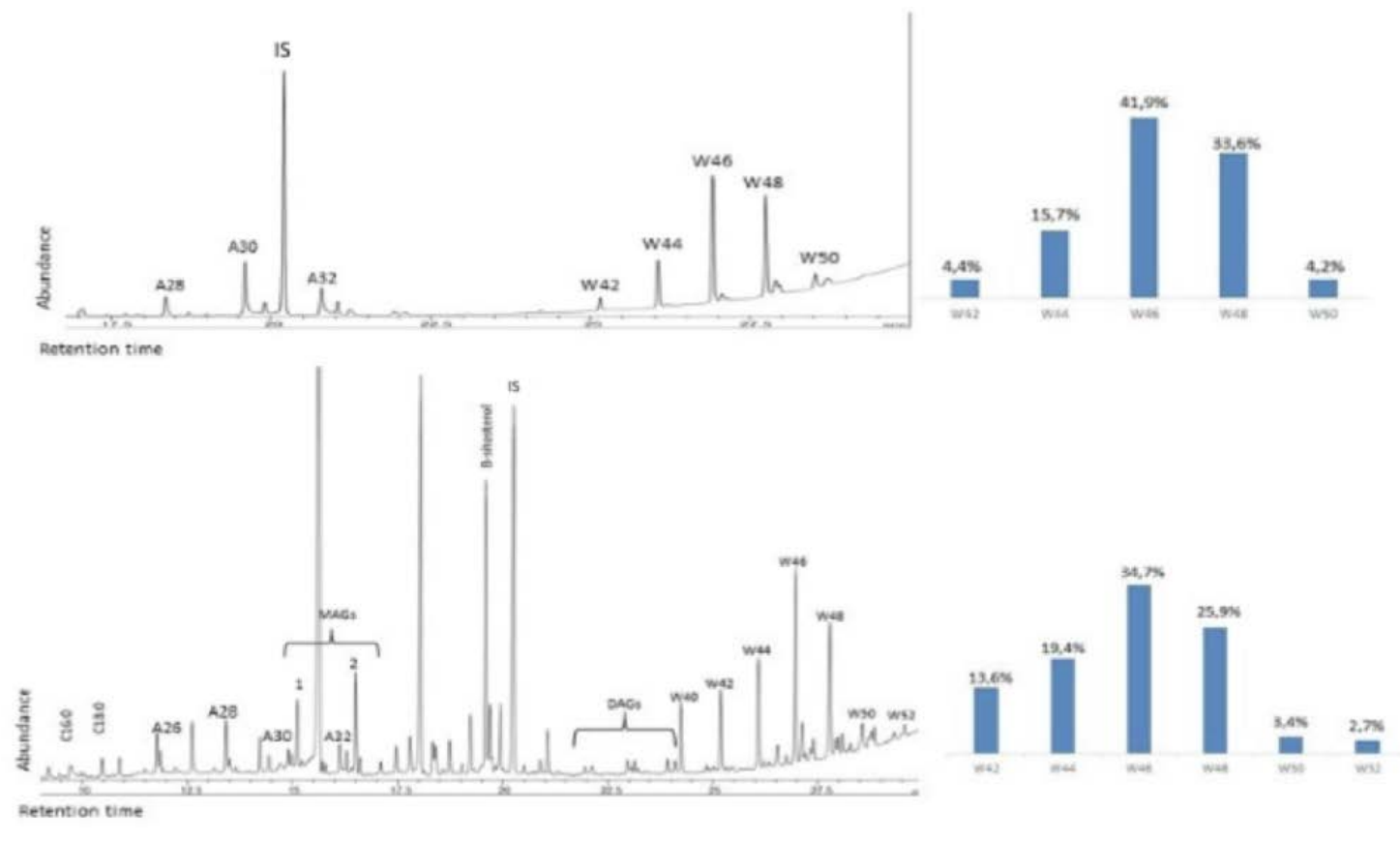

Figure 6. Gas chromatograms (left) showing the distribution of fatty alcohols and wax esters from

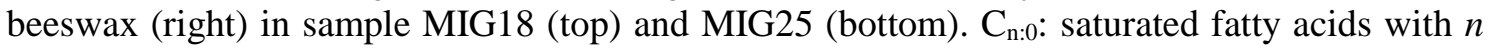
carbon atoms; $\mathrm{A}_{\mathrm{n}}$ : alkanes; $\mathrm{W}_{\mathrm{n}}$ : was esters; IS: internal standard, $\mathrm{C}_{34} n$-tetratricontane.

\subsection{Pottery characteristics}

The mean volume of the analyzed vessels was $0.54 \mathrm{~L}$, with a range from $0.2 \mathrm{~L}$ to $1.21 \mathrm{~L}$ (Table 1). This estimated volume is relatively small, which limits their functional diversity (Rice, 2015; Vieugué et al., 2008). These results were compared with those obtained for the pottery studied from the analysis of organic residues in ceramics from other domestic sites. In the review of vessels from Southern European Neolithic sites that 
combine morphometric and biomolecular studies (Drieu, 2017; Fanti et al., 2018; Matlova et al., 2017; Šoberl et al., 2014; Vieugué et al., 2008), we can see a higher volumetric mean size (from $>2.5 \mathrm{~L}$ to $<5 \mathrm{~L}$ ) with regard to the vessels analyzed in Mines de Gavà, being able to distinguish different functional categories that respond to the service, processing and storage of both solid and liquid products. The relative homogeneity of volumes for the pottery from Mines de Gavà may thus be due to the mining context and could respond to particular functions.

There was no correlation between the volume or openness index of the vessels and the specific function identified from ORA results. Therefore it is unlikely that specific forms had a specific function. A similar lack of correlation was observed with funerary vessels, as varied morphologies and different commodities were identified. In contrast, vessels that contained beeswax and those where plant input has been identified are characterised by an open shape.

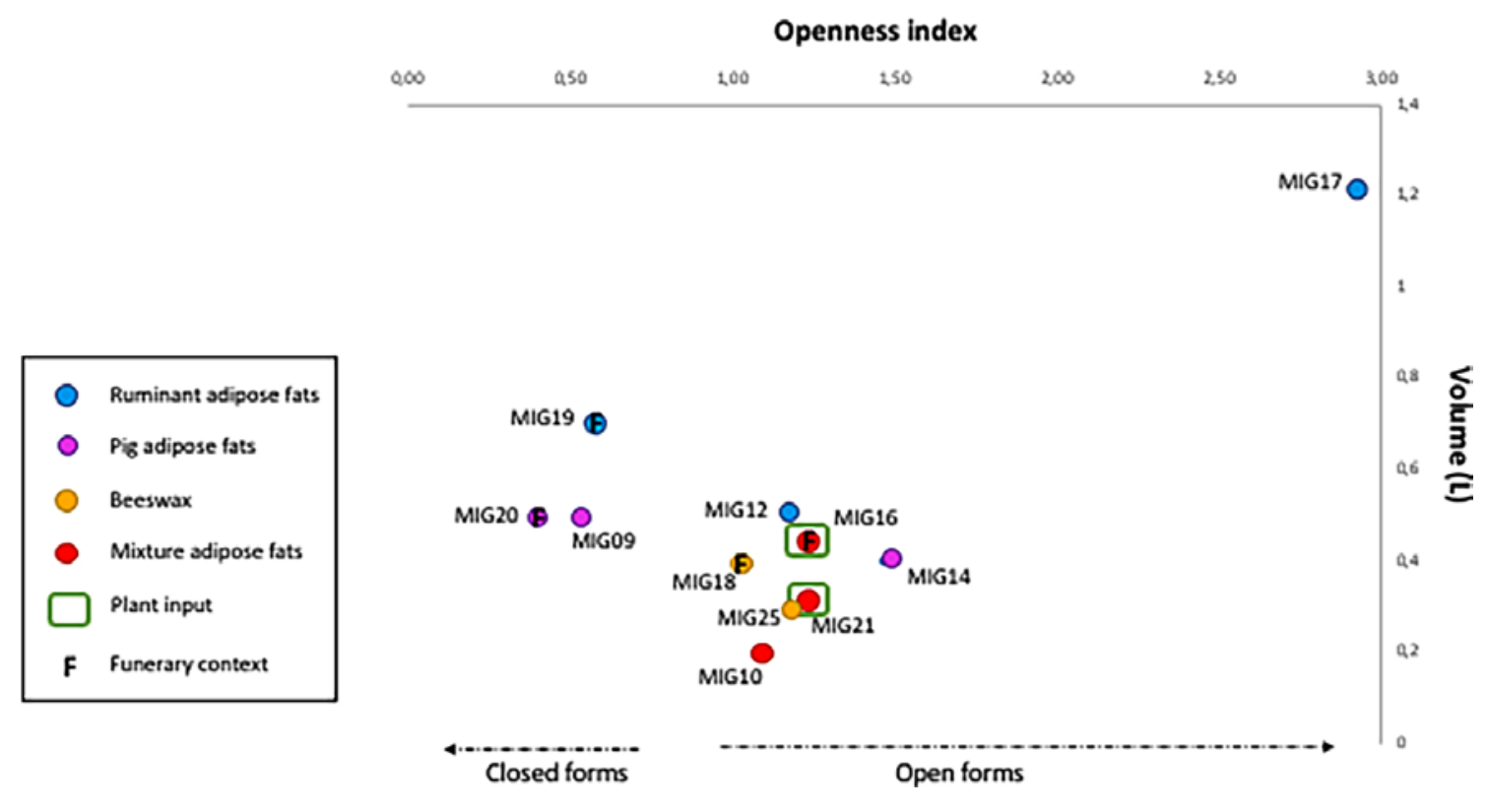

Figure 7. Scatter plot of the volume and opening index (maximum diameter / orifice diameter) of the Mines de Gavà vessels related to the commodities identified inside. The vases identified in funerary context are also specified. 


\section{Discussion}

\subsection{Lipid preservation}

The results from the lipid biomarkers identified in the pottery extracts highlight the presence of a significant diversity of natural substances used in the original ceramic vessels. There were mostly of animal origin. Ruminant and non-ruminant adipose fats were identified in most of the vessels based on molecular and stable carbon isotopic criteria, and beeswax was present in two small bowls. Figure S1 (supplementary information) summarizes the data obtained by grouping together containers having similar contents.

Among the total lipid concentration obtained, no significant differences are observed between lipid concentrations at the rim (mean $228 \mu \mathrm{g} \cdot \mathrm{g}^{-1}$ ) or in the samples taken at the base of the vessel (mean $151 \mu \mathrm{g} \cdot \mathrm{g}^{-1}$ ). Experimental studies showed that boiling of food products resulted in a higher concentration of lipids in the upper part of the vessel (Charters et al., 1993; Evershed et al., 1995; Roffet-Salque, 2012), while roasting, due to the production of water and fat from the meat during processing, resulted in a lipid concentration evenly distributed throughout the vessel (Evershed, 2008). However, to go further in the understanding of the use of vessels, it would be necessary to obtain at least two samples for vessel. This was not possible in the present study due to preservation conditions. At this stage of our study, we can just note that the concentration appears to be generally higher in vases from the rim of the vessels than from other parts. However, in any discussion about relative concentrations of lipids within pottery, we must be mindful of the taphonomic processes that sherds could have suffered. Higher concentrations of lipids in some vessels possibly reflect the repetitive use of vessels, as well as an extended use-life or the processing of commodities rich in lipids. In contrast, vases with lower recovery rates and lower concentrations of lipids may reveal a specialization in the use of the container, or that its use is not related to cooking or processing of fat-rich foodstuffs or had shortened use-life due to early breakage of the vessels (Matlova et al., 2017). Finally, there are some vases where we did not detect lipid residues. Despite not having a reconstruction of the profile corresponding to these vessels, we propose that the absence of lipids relates to the specific uses of these containers, which do not imply direct contact with fatty foods, such as the transport and/or storage of water or dry seeds, or loss of lipids due to degradation. 


\subsection{Presence of animal fats}

The faunal remains are characterized by the presence of the four main domestic taxa, cattle (Bos taurus) (45\%), sheep (Ovis aries) and goats (Capra hircus) (28\% together), and pigs (Sus domesticus) (27 \%) (Saña, 1994). This is evidence for different treatment of the animals at the site. Some of bones showed butchering marks and signs of thermal alteration, related to the boiling and roasting (Navarrete et al., in press). Other remains, especially bovine bones, were most likely used to make tools (Estevez, 1986). Faunal remains of wild species, such as wild boar, rabbit or deer are present but of lesser importance (Bosch and Estrada, 1994). Generally, animals were slaughtered at young age for meat exploitation (Estévez, 1986; Saña, 1994). Some cattle lived longer, which might indicate their use for transport of heavy loads, traction related to agriculture or for dairying. The absence of molecular and isotopic signatures of dairy products on the pottery analyzed from Mines de Gavà would imply that the former is more likely. However, it is difficult to completely rule out dairy products at this site. Identification of dairy fats is especially difficult if they are mixed with other animal fats in pottery, or else milk might have been stored or processed in perishable leather or wooden containers (Maigrot, 2003; Morris, 2013).

The use of animal fats, especially pig fat, is also proposed as a post-firing waterproofing treatment based on ethnographic data (Evershed et al., 1997; Skibo, 2013). This hypothesis is reinforced by the absence of ketones. The detection of asymmetric ketone with 33 carbon atoms along with other asymmetric ketones are considered, along with the long-chain $\omega$-(o-alkylphenyl)alkanoic acids (APPAs), markers of thermal transformation of animal fats (Evershed et al., 1995; Raven et al., 1997). Therefore, there is no evidence that the vessels are used for cooking or processing fatty products. All this suggests that some vessels could have been used for the service and consumption of products (perhaps liquids) waterproofed with animal fat. For the same reason, we can also observe a mixture of animal fats in some containers (MIG10, MIG16, MIG21), in which pork fat probably waterproofed the surface and which were used to process other animal fats that would also have been preserved in the clay matrix. However, differential heating of the fabric or short episodic heating might easily explain the APPAs absence (Bondetti et al., 2020).

Among the different possible uses of animal fats (foodstuff, waterproofing...), it can also be transformed into animal fat into tallow. Tallow is often used to make soap, as a 
lubricant, in skin products and candles (Shillito, 2019). Tallow is produced when fat is boiled, a process that separates it from bones and proteins (Frith et al., 2004). Tallow extracted from cattle and sheep is hard, while pig fat produces a softer grease product (lard). The possible production of tallow and lard leads us to suggest that lamps fuelled with animal fat could also have been used to illuminate the long dark galleries of the Mines of Gavà. Of course, not all vessels have optimal morphologies and metric characteristics to be used as lamps (see Supplementary Material and Figure 7). MIG09, MIG19 and MIG20 samples correspond to recipients with narrow necks that relate to their use for liquid or semi-liquid food processing. The same applies to sample MIG17, a sherd from a ceramic having large dimensions that are impractical to transport and more suitable for food processing or service. On the other hand, the vessels corresponding to samples MIG18 and MIG25 (where traces of beeswax have been detected), MIG11, MIG12, MIG14 and MIG21, present shapes more compatible with their interpretation as lamps. In these potential lamps, we have detected both ruminant and pig fats, sometimes even together with plant biomarkers, which led us to think about the use of these products as possible fuel to illuminate (Kimpe et al., 2001; Mottram et al., 1999; Roffet-Salque et al., 2017; Shillito, 2019). However, no carbonized deposits attached to the ceramic surfaces have been detected, evidence that would help us defend the hypothesis of the lamps. This may be due to the washing and restoration processes to which the containers were subjected for their exhibition in the museum. The interpretation of adipose fats as a production of tallow is very tentative and it does not exclude feasting on pigs and ruminants and, indeed, might correspond to one of the various uses of animal fat, comprising both food and non-food uses (Shillito, 2019).

\subsection{Beeswax use}

The pottery from Mines de Gavà in which traces of beeswax have been identified represent the oldest evidence reported so far of the use of such a substance in the Iberian Peninsula (Roffet-Salque et al., 2017). Its hydrophobic properties have made it suitable for use as a material to waterproof pottery (Charters et al., 1995; Heron et al., 1994; 2015, Knappett et al., 2005; Rageot et al., 2015; Roffet-Salque et al., 2013; Regert et al., 2001a; Roumpou et al., 2003). The hypothesis of using beeswax as a waterproofing agent for pottery surfaces is more likely when there is no heating trace on the sherds and when the beeswax signal is only slightly degraded (Mirabaud and Regert, 2016). Once sealed with this product, the vessels were probably not used as cooking vessels given the rather low 
melting point of the wax (60 ${ }^{\circ} \mathrm{C}$; Drieu, 2017; Regert et al., 2001a). However, moderate wax heating can soften it to facilitate its application to surfaces (Heron et al., 1994).

Beeswax has been found in Mines de Gavà either alone or mixed with animal fats in two recipients. Vessels in which beeswax has been identified are open-shaped and shallow containers (see Supplementary Material and Figure 7). The presence of beeswax on the internal surface of the containers may respond to the use as a waterproofing agent for the processing of other products, such as animal fats, or there may be two separate uses of the potsherds or traces of a mixture of honey with other foods (Mirabaud and Regert, 2016; Roffet-Salque et al., 2015). However, given the particular shape of the containers and the context in which they were found, it can be envisaged that the containers could have been used for beeswax lamps. This would not be the first case in which beeswax has been identified as an illuminant in antiquity (Evershed et al., 1997; Frith et al., 2004; Roffet-Salque et al., 2017). This use can be attributed to the fact that beeswax burns very slowly. The absence of soot on the surface of the potsherds can be attributed to the fact that slow burning of pure beeswax does not produce soot (Asperger et al., 1999). The identification of wax and animal fats (mixed or not) interpreted as fuel for lighting is explained in other cases by the inaccessibility and cost of obtaining beeswax (Crane, 1980; 2011; Frith et al., 2004; Knight, 1918; Mottram et al., 1999; Regert, 2011). Indeed, we do not know if, at that time, beeswax was obtained from domestic or wild beehives. In the second case, the amount of beeswax was probably low. The exceptionality of the context in which the containers were found, inside some mines and in a funerary context, reinforces the hypothesis of the use of beeswax as an illuminant as burial goods or to illuminate mine galleries in some unusual circumstances. 


\section{Conclusions}

Analysis of organic residues preserved in archaeological ceramics using analytical organic chemical techniques led to the identification of vessel organic contents from the Middle Neolithic site of Mines de Gavà. The conditions similar to those prevailing in a cave, with low and stable temperature and low variation of humidity, have made it possible to recover a large part of the lipids absorbed in the ceramic matrix. This study has shown the exploitation of animal fats from both ruminants and pigs, as well as plants and beeswax in Mines de Gavà. These results not only reinforce the information obtained from the archaeozoological and carpological remains found on the site, but also provide new data that can only be obtained by applying specific analytical techniques, such as the chromatographic analysis of organic residues in pottery. Thus, the occurrence of beeswax documented in two vessels represents the first evidence of the exploitation of this resource in the site of the Mines de Gavà, and the oldest evidence reported so far in the Iberian Peninsula.

The relationship between shape, volume and content of the ceramics has allowed us to propose different alternative uses for the commodities identified on the vessels, where there is little variety in the morphology of the vessels with a small volume, unlike other sites in the domestic context. Given the different uses that the mines received, the results of organic residues in ceramics do not show a differentiation between the contents of the vessels of the different mines. Generally, vessels were used to process fats from animal or vegetal origin. Likewise, other vessels have been proposed to be used for the illumination of the dark galleries either in a funerary context, as in mine 84 (Borrell et al., 2019), and during the extraction works of the variscite, as the container of mine 41 . The hypothesis proposed, derived from a pioneering study in this area, should undoubtedly be contrasted with new studies that would expand the sample set in other different mines from this site.

Finally, the results obtained from the organic residues eventually preserved in the clay matrix of the containers in Mines de Gavà allow us to provide new data to the discussion on the presence and proximity of a settlement in the vicinity of the mines. 


\section{Acknowledgments}

This study has been developed in the framework of research projects $\mathrm{I}+\mathrm{D}$ “Arqueobioquímica de la alimentación durante el Neolítico Peninsular: Nuevos marcadores y referenciales para el estudio de las pautas de producción y consumo en Arqueología” [HAR2017-88304-P] (2017-2020); “Producción animal y cerámica en el Neolítico peninsular. Estudio biogeoquímico integrado del consumo y las prácticas culinarias” [HAR2014-60081-R] (2014-2017) and "Mines Prehistòriques de Gavà. Espai i temps, dinàmica evolutiva i caracterització mineralògica" [Generalitat de Catalunya Exp. 2014/100820] (2014-2017). This paper has been written during a postdoctoral grant from the Fyssen Foundation. Núria Moraleda and Pau Comes are thanked for analytical suport and isotòpic measurement at ICTA-UAB. The authors are grateful to the revisions of Pierre Adam and Philippe Schaeffer, the contextualization of the site of Josep Bosch (Director of Gavà Museum) and the fruitful discussion on lighting with Pierre-Alain Gillioz. 


\section{References}

Asperger, A., Engewald, W. R., Fabian, G. (1999). Advances in the analysis of natural waxes provided by thermally assisted hydrolysis and methylation (THM) in combination with GC/MS. Journal of Analytical and Applied Pyrolysis, 52, 51-63. DOI: 10.1016/S0165-2370(99)00039-X

Bagolini, B., Pedrotti, A. (1998). Néolithique moyen et récent d'Italie septentrionale, culture des vases à embouchure carrée. Atlas du Néolithique européen, 2, 253-262.

Bazzanella, M. (1999). Les vases à ouverture carrée en Europe Occidentale. La culture de Cerny. Nouvelle économie, Couvelle societé au Néolithique, 1-18.

Blasco, M., Borrell, M., Bosch, J. (2000). Las minas prehistóricas de Gavá (Barcelona): Un ejemplo de estudio, conservación y presentación publica de un yacimiento arqueológico. Trabajos de Prehistoria, 57, 77-87. DOI: 10.3989/tp.2000.v57.i2.249

Bondetti, M., Lucquin, A., Savel'ev, N. A., Weber, A. W., Craig, O. E., Jordan, P. D. (2020). Resource processing, early pottery and the emergence of Kitoi culture in Cis-Baikal: Insights from lipid residue analysis of an Early Neolithic ceramic assemblage from the Gorelyi Les habitation site, Eastern Siberia. Archaeological Research in Asia, 24, 100225. DOI: 10.1016/j.ara.2020.100225

Bordas, A., Borrell, F., Bosch, J. (2009). 10 anys de recerques arqueològiques a la serra de les Ferreres (Mines de Gavà, Baix Llobregat). In: Bosch, J., Borrell, F. (coord) Rubricatum 4. Revista del Museu de Gavà: de la variscita al ferro: neolític i antiguitat. Museu de Gavà, Gavà, 9-14.

Borrell, F. (2009). La indústria lítica neolítica tallada en sílex de les mines 83, 84, 85 i 90 (Gavà, Baix Llobregat): morfología i tecnología. In Bosch, J., Borrell, F. (coords.) Rubrica- tum. Revista del Museu de Gavà : Intervencions arqueològiques a les Mines de Gavà (Sector Serra de les Ferreres). Anys 1998-2009, 4, 109-124.

Borrell, F., Bosch, J., Gibaja, J. F., Schmidt, P., Terradas, X. (2019). The status of imported BarremianBedoulian flint in north-eastern Iberia during the Middle Neolithic. Insights from the variscite mines of Gavà (Barcelona). PLoS ONE, 14 (11) https://doi.org/10.1371/journal. pone.0224238

Borrell, F., Bosch, J. (2012) Las minas de variscita de Gavà (Barcelona) y las redes de circulación en el Neolítico. In Borrell, F., Bosch, J., Clop, X., Molist, M. (coords.) Rubricatum. Revista del Museu de Gavà: Xarxes del Neolític. Circulació i intercanvi de matèries, productes i idees a la Mediterrània occidental (VII-III mil·lenni aC), 5, 315-322.

Bosch, J. (2010). Representaciones antropomorfes muebles del Neolítico en Cataluña: primeros ídolos oculados. In: Cacho, C., Maicas, R., Galán, E., Martos, J. A. (coord) Ojos que nunca se cierran. Ídolos en las primeres sociedades campesinas. Museo Arqueológico Nacional, Madrid, 13-37.

Bosch, J. (1994). Estudi dels materials. Objectes de fang sense coure. In: Bosch, J., Estrada, A. (coord) Rubricatum. Revista del Museu de Gavà: el Neolític Postcardial a les Mines Prehistòriques de Gavà (Baix Llobregat). Museu de Gavà, Gavà, 172 - 177.

Bosch, J., Gómez, A., Calvo, S., Molist, M. (2019). Green beads during the Late Prehistory in the northeast Iberian Peninsula: social dynamics in a production and consumption context. In: Rodríguez-Rellán C., Nelson, B. A., Fábregas Valcarce, R. (eds.). A taste of green. A global perspective on ancient jade, turquoise and variscita exchange. Oxbow books, Oxbow \& Philadelphia.

Bosch, J., Santacana, J. (2009). Blat, metalls cabdills: Catalunya del Neolític a la iberització. Barcelona.

Bosch, J., Estrada, A. (1993). Noves aportacions al Neolític Antic Postcardial (fàcies Molinot): Les Mines Prehistòriques de Gavà. Miscel-lània Penedesenca, 6enes Jornades d'Estudis Penedesencs, Arboç 4, 5 i 6 de Juny de 1993, 18, Institut d'Estudis Penedesencs, Vilafranca del Penedès, 87 - 100.

Bosch, J., Estrada, A. (1994). El Neolitic Postcardial a les mines prehistoriques de Gavà (sector serra de les Ferreres), anys 1998-2009. Rubricatum, 4.

Bosch, J., Estrada, A., Segura, M.T. (1994). "Estudi dels materials. Ceràmica”. En: Bosch, J., Estrada, A. (Coord.) Rubricatum: revista del Museu de Gavà: El neolític postcardial a les Mines Prehistòriques de Gavà (Baix Llobregat), 5, Gavà: Museu de Gavà, 53-121.

Bosch, J., Estrada, A. (1998). L'estudi de la minería neolítica a Gavà en el seu context ambiental i socioeconòmic". En: Bosch, J., Terradas, X., Orozco, T. (Eds.), Rubricatum. Revista del Museu de Gavà: Actes de la 2a Reunió de Treball sobre Aprovisionament de Recursos Lítics a la Preshistòria. Barcelona Gavà 26, 27, 28 November 1997, 2, Gavà: Museu de Gavà, 137 - 144.

Breu, A. (2019). Earliest pottery uses in north-eastern Iberia. Organic residue analysis on vessels from the first farmers and herders. Universitat Autònoma de Barcelona, PhD Thesis. 
Buxó, R. (2007). Crop evolution: new evidence from the Neolithic of west Mediterranean Europe. In Colledge, S., Conolly, J. (eds.). The origin and spread of domestic plants in Southwest Asia and Europe. Walnut Creek, Left Coast Press, 155-171.

Calvo, S. (2019). Aproximación y caracterización de la tecnología de fabricación de los recipientes cerámicos en las Minas Prehistóricas de Gavà. PhD thesis, Universitat Autònoma de Barcelona.

Carrer, F., Colonese, A. C., Lucquin, A., Guedes, E. P., Thompson, A., Walsh, K., Reitmaier, T., Craig, O. E. (2016). Chemical analysis of pottery demonstrates prehistoric

origin for high-altitude alpine dairying. PloS one 11, 4. DOI: e0151442.

Charters, S., Evershed, R., Blinkhorn, P., Denham, V. (1995) Evidence for the mixing of fats and waxes in archaeological ceramics. Archaeometry, 37, 113-127. DOI: 10.1111/j. 1475-4754.1995.tb00730.x

Charters, S., Evershed, R. P., Goad, L. J., Leyden, A., Blinkhorn, P. W. Denham, V. (1993). Quantification and distribution of lipid in archaeological ceramics: implications for sampling potsherds for organic residue analysis and the classification of vessel use. Archaeometry, 35, 211-223. DOI: 10.1111/j.1475-4754.1993.tb01036.x

Clop, X., Álvarez, A. (2009). Estudi de caracterització petrogràfica d'un vas de boca qua- drada neolític de la mina 83 de Gavà. In: Bosch, J., Borell, F. (Coord). Rubricatum. Revista del museu de Gavà: Intervencions arqueològiques a les Mines de Gavà (Sector Serra de les Ferreres). Anys 1998 - 2009, 4, Gavà: Institut Municipal de Gestió del Patrimoni Cultural i Natural. Ajuntament de Gavà, 85 - 91.

Colonese, A. C., Lucquin, A., Guedes, E.P., Thomas, R., Best, J., Fothergill, B.T.,

Sykes, N., Foster, A., Miller, H., Poole, K., Maltby, M., Von Tersch, M., Craig, O. E. (2017). The identification of poultry processing in archaeological ceramic vessels using in-situ isotope references for organic residue analysis. Journal of Archaeological Science, 78: 179-192. DOI: 10.1016/j.jas.2016.12.006

Copley, M. S., Berstan, R., Mukherjee, A. J., Dudd, S. N., Straker, V., Payne, S., Evershed, R. P. (2005a). Lacticing in antiquity III. Evidence from absorbed lipid residues dating to the British Neolithic. Journal of Archaeological Science, 32, 523-546.

Copley, M. S., Bland, H. A., Rose, P., Horton, M. Evershed, R. P. (2005b). Gas chromato- graphic, mass spectrometric and stable carbon isotopic investigations of organic residues of plant oils and animal fats employed as illuminants in archaeological lamps from Egypt. Analyst, 130, 860-871. DOI: 10.1039/b500403a

Copley, M. S., Hansel, F. A., Sadr, K., Evershed, R. P. (2004). Organic residue evidence for the processing of marine animal products in pottery vessels from the pre-colonial archaeological site of Kasteelberg D east, South Africa. South African Journal of Science 100, 279-283.

Copley, M. S., Berstan, R., Dudd, S. N., Docherty, G., Mukherjee, A. J., Straker, V., Evershed, R. P. (2003). Direct chemical evidence for widespread dairying in prehistoric Britain. Proceedings of the National Academy of Sciences of the United States of America, 100, 1524-1529. DOI: 10.1073/pnas.0335955100

Copley, M. S., Rose, P. J. C., A., Edwards, D. N., Horton, M. C., Evershed, R. P. (2001).Processing palm fruits in the Nile Valley - biomolecular evidence from Qasr Ibrim.Antiquity, 75, 538-542. DOI: 10.1017/S0003598X00088761

Courel, B., Robson, H.K., Lucquin, A., Dolbunova, E., Oras, E., Adamczak, K., Andersen, S.H., Astrup, P.M., Charniauski, M., Czekaj-Zastawny, A., Ezepenko, I., Hartz, S., Kabaciński, J., Kotula, A., Kukawka, S., Loze, I., Mazurkevich, A., Piezonka, H., Piličiauskas, G., Sørensen, S.A., Talbot, H.M., Tkachou, A., Tkachova, M., Wawrusiewicz, A., Meadows, J., Heron, C.P., Craig, O.E. (2020). Organic residue analysis shows sub-regional patterns in the use of pottery by Northern European hunter-gatherers. Royal Society Open Science, 7. DOI:10.1098/rsos.192016

Craig, O. E., Saul, H., Lucquin, A., Nishida, Y., Taché, K., Clarke, L., Thompson, A., Altoft, D. T., Uchiyama, J., Ajimoto, M., Gibbs, K., Isaksson, S., Heron, C., Jordan, P. (2013). Earliest evidence for the use of pottery. Nature 496: 351-354.

Craig, O. E., Allen, R. B., Thompson, A., Stevens, R. E., Steele, V. J., Heron, C. (2012). Distinguishing wild ruminant lipids by gas chromatography/combustion/isotope ratio mass spectrometry. Rapid Communications in Mass Spectrometry 26: 2359-2364.

Craig, O. E., Steele, V. J., Fischer, A., Hartz, S., Andersern, S. H., Donohoe, P., Glykou, A., Saul, H., Jones, D. M., Koch, E., Heron, C. P. (2011). Ancient lipids reveal continuity in culinary practices across 
the transition to agriculture in Northern Europe. Proceedings of the National Academy of Sciences of the United States of America, 44, 17910-17915. DOI: 10.1073/pnas.1107202108

Craig, O. E., Forster, M., Andersen, S. H., Koch, E., Crombe, P., Milner, N. J., Stern, B., Bailey, G. N., Heron, C. (2007). Molecular and isotopic demonstration of the processing of aquatic products in northern European prehistoric pottery. Archaeometry, 49, 135-152. DOI: 10.1111/j.14754754.2007.00292.x

Cramp, L., Jones, J., Sheridan, A., Smyth, J., Whelton, H., Mulville, J., Sharples, N., Evershed, R. P. (2014). Immediate replacement of fishing with lacticing by the earliest farmers of the Northeast Atlantic archipelagos. Proceedings of The Royal Society. Biological Sciences, 281, 1-8. DOI: 10.1098/rspb.2013.2372

Crane, E. E. (2011). The world history of beekeeping and honey hunting. International Bee Research Association, London.

Crane, E. E. (1980). A book of honey. Oxford University Press, Oxford.

Cubas, M., Lucquin, A., Robson, H.K., Colonese, A. C., Arias, P., Aubry, B., Billard, C., Jan, D., Diniz, M., Fernandes, R., Fábregas Valcarce, R., Germain-Vallé, C., Juhel, L., de Lombera-Hermida, A., Marcigny, C., Mazet, S., Marchand, G., Neves, C., Ontañón-Peredo, R., Rodríguez-Álvarez, X. P., Simoes, T., Zilhao, J., Craig, O. E. (2020). Latitudinal gradient in dairy production with the introduction of farming in Atlantic Europe. Nature Communications, 11. DOI: 10.1038/s41467-02015907-4

Cubas, M., Sánchez Carro, M. Á., Roig, J., Coll Riera, J. M., Gibaja, J. (2017). Chapter thirty one: Pottery for the dead: exploring raw materials exploitation in the pottery of Can Gambús-1 (Sabadell, Catalonia). In: Pereira, T., Terradas, X., Bicho, N. (Eds.). The Exploitation of Raw Materials in Prehistory. Sourcing, Processing and Distribution. Cambridge Scholars Publishing: 449-462.

Donoso, G. (1998). El estudio tipológico del utillaje fabricado sobre corneana en el yacimiento neolítico de las "Mines prehistòriques de Gavà - Can Tintorer. In: Bosch, J., Terradas, X., Orozco, T. (Eds) Rubricatum. Revista del Museu de Gavà: Actes de la 2a Reunió de Treball sobre Aprovisionament de Recursos Lítics a la Preshitòria. Barcelona - Gavà 26, 27, 28 November 1997, 2, Gavà: Museu de Gavà, 137 - 144.

Drieu, L. (2017). Fabrication et usages des poteries durant le Néolithique et la Protohistoire en Europe: les apports de l'archéologie biomoléculaire. PhD thesis, Université Côte d'Azur.

Drieu, L., Mirabaud, S., Roffet-Salque, M., Blasco, T., Pétrequin, P., Pétrequin, A.-M., Evershed, R. P., Regert, M. (2020). Defining pottery use and exploitation of natural products at Clairvaux XIV during the Middle Neolithic. In: Hafner, A., Dobunova, E., Mazurkevich, Planckenaite, E., Hinz, M. (eds.) Settling waterscapes in Europe: the archaeology of Neolithic and Bronze Age pile-dwellings, Proceedings of the EAA 2016 (Vilnius, Lituanie), 249-271.

Drieu, L., Lucquin, A., Cassard, L., Sorin, S., Craig, O. E., Binder, D., Regert, M. (Under revision). A Neolithic without dairy? Chemical evidence from the content of ceramics from the Pendimoun rockshelter (Castellar, France, 5750-5150 BCE). Journal of Archaeological Science: Reports.

Dudd, S. N. (1999). Molecular and isotopic characterisation of animal fats in archaeological pottery. PhD thesis, University of Bristol.

Dudd, S. N., Evershed, R. P. (1998). Direct demonstration of milk as an element of archaeological economies. Science, 282, 1478-1481. DOI: 10.1126/science.282.5393.1478

Dudd S., Evershed R. P., Gibson A. M. (1999) Evidence for varying patterns of exploitation of animal products in different prehistoric pottery traditions based on lipids preserved in surface and absorbed residues. Journal of Archaeological Sciences, 26, 1473-1482.

Dunne, J., Evershed, R. P., Salque, M., Cramp, L., Bruni, S., Ryan, K., Biagetti, S., di Lernia, S. (2012). First lacticing in green Saharan Africa in the fifth millennium BC. Nature, 486, 390-394.

Dunne, J., di Lernia, S., Chłodnicki, M., Kherbouche, F., Evershed, R. P. (2018). Timing and pace of dairying inception and animal husbandry practices across Holocene North Africa. Quaternary International, 471, 147-159. DOI: 10.1016/j.quaint.2017.06.062

Dunne, J., Mercuri, A. M., Evershed, R. P., Bruni, S., di Lernia, S. (2016). Earliest direct evidence of plant processing in prehistoric Saharan pottery. Nature Plants, 3, 1-6. DOI: 10.1038/nplants.2016.194

Estévez, J. (1986). “Estudi de la fauna”. En: Villalba, M.J., Bañolas, L., Arenas, J. y Alonso, M. (1986). Les Mines neolítiques de Can Tintorer. Gavà. Excavacions de 1978-1980. Barcelona: Departament de Cultura de la Generalitat de Catalunya., 171 - 196. 
Ethier, J., Bánffy, E., Vuković, J., Leshtakov, K., Bacvarov, K., Roffet-Salque, M., Ivanova, M. (2017). Earliest expansion of animal husbandry beyond the Mediterranean zone in the sixth millennium BC. Scientific Reports, 7, 1-10. DOI: 10.1038/s41598-017-07427-x

Evershed, R. P. (2008). Organic residue analysis in archaeology: the archaeological biomarker revolution. Archaeometry, 50, 895-924. DOI: 10.1111/j.1475-4754.2008.00446.x

Evershed, R. P., Copley, M. S., Dickson, L., Hansel, F. A. (2008a). Experimental evidence for the processing of marine animal products and other commodities containing poly-unsaturated fatty acids in pottery vessels. Archaeometry, 50, 101-113. DOI: 10.1111/j.1475-4754.2007.00368.x

Evershed, R. P., Payne, S., Sherratt, A. G., Copley, M. S., Coolidge, J., Urem-Kotsou, D., Kotsakis, K., Özdoğan, M., Özdoğan, A. E., Nieuwenhuyse, O., Akkermans, P. M. M. G., Bailey, D., Andeescu, R. R., Campbell, S., Farid, S., Hodder, I., Yalman, N., Özbaşaran, M., Biçakci, E., Garfinkel, T., Levy, T., Burton, M. M. (2008b). Earliest date for milk use in the Near East and southeastern Europe linked to cattle herding. Nature, 455, 528-531. DOI: 10.1038/nature07180

Evershed, R. P., Vaughan, S. J., Dudd, S. N., Soles, J. S. (1997). Fuel for thought? Beeswax in lamps and conical cups from Late Minoan Crete. Antiquity, 71, 979-985. DOI: 10.1017/S0003598X00085860

Evershed, R. P., Charters, S. Quye, A. (1995). Interpreting lipid residues in archaeological ceramics: preliminary results from laboratory simulations of vessel use and burial. Materials Research Society Symposium Proceedings, 352, 85. DOI: 10.1557/PROC-352-85

Fanti, L., Drieu, L., Mazuy, A., Blasco, T., Lugliè, C., Regert, M. (2018). The role of pottery in Middle Neolithic societies of western Mediterranean (Sardinia, Italy, 4500-4000 cal BC) revealed through an integrated morphometric, use-wear, biomolecular and isotopic approach. Journal of Archaeological Science, 93, 110-128. DOI: 10.1016/j.jas.2018.03.005

Frith, J., Appleby, R., Stacey, R., Heron, C. (2004). Sweetness and light: chemical evidence of beeswax and tallow candles at Fountains Abbey, North Yorkshire. Medieval Archaeology, 48, 220-227. DOI: $10.5284 / 1071958$

García-Atiénzar, G. (2009). Territorio neolítico: las primeras comunidades campesinas en la fachada oriental de la Península Ibérica (ca. 5600-2800 cal BC). Oxford, Archaeopress.

Garnier, N., Cren-Olivé, C., Rolando, C. Regert, M. (2002). Characterization of archaeological beeswax by electron ionization and electrospray ionization mass spectrometry. Analytical Chemistry, 74, 48684877. DOI: 10.1021/ac025637a

Gillis, R. E., Kovaciková, L., Bréhard, S., Guthmann, E., Vostrovská, I., Nohálová, H., Arbogast, R.-M., Domboróczki, L., Pechtl, J., Anders, A., Marciniak, A., Tresset, A., Vigne, J.-D. (2017). The evolution of dual meat and milk cattle husbandry in Linearbandkeramik societies. Proceedings Royal Society B, 289. DOI: 10.1098/rspb.2017.0905

Gregg, M. W., Banning, E. B., Gibbs, K., Slater, G. F. (2009). Subsistence practices and pottery use in Neolithic Jordan: molecular and isotopic evidence. Journal of Archaeological Science, 36, 937-946. DOI: $10.1016 /$ j.jas.2008.09.009

Hammann, S., Cramp L. J. E. (2018). Towards the detection of dietary cereal processing through absorbed lipid biomarkers in archaeological pottery. Journal of Archaeological Science, 93: 74-91. DOI: 10.1016/j.jas.2018.02.017

Hamilton, J., Hedges, R. E. M., Robinson, M. (2009). Rooting for pigfruit: pig feeding in Neolithic and Iron Age Britain compared. Antiquity, 83, 998-1011. DOI: 10.1017/S0003598X00099300

Hansel, F. A., Copley, M. S., Madureira, L. A. S., Evershed, R. P. (2004). Thermally produced w-(oalkylphenyl)alkanoic acids provide evidence for the processing of marine products in archaeological pottery vessels. Tetrahedron Letters, 45, 2999-3002. DOI: 10.1016/j.tetlet.2004.01.111

Heron, C., Shoda, S., Breu Barcons, A., Czebreszuk, J., Eley, Y., Gorton, M., Craig, O. E. (2016). First molecular and isotopic evidence of millet processing in prehistoric pottery vessels. Scientific Reports, 6. DOI: $10.1038 /$ srep38767

Heron, C., Craig, O. E., Luquin, A., Steele, V. J., Thompson, A., Pilikiauskas, G. (2015). Cooking fish and drinking milk? Patterns in pottery use in the southeastern Baltic, 3300- 2400 Cal BC. Journal of Archaeological Science, 63, 33-43. DOI: 10.1016/j.jas.2015.08.002

Heron, C., Nemcek, N., Bonfield, K., Dixon, D. Ottaway, B. (1994). The chemistry of Neolithic beeswax. Naturwissenschaften 81, 266-269. DOI: 10.1007/bf01131579

Horiuchi, A., Miyata, Y., Kamijo, N., Cramp, L., Evershed, R. P. (2015). A dietary study of the Kamegaoka culture population during the Final Jomon Period, Japan, using 
stable isotope and lipid analyses of ceramic residues. Radiocarbon 57: 721-736.

Isaksson, S., Hallgren, F. (2012) Lipid residue analyses of Early Neolithic funnel-beaker pottery from Skogmossen, Eastern Central Sweden, and the earliest evidence of lacticing in Sweden. Journal of Archaeological Science, 39, 3600-3609. DOI: 10.1016/j.jas.2012.06.018

Karasik, A., Smilanski, U. (2006). Computation of the capacity of pottery vessels based on drawn profiles. In: Mazar, A. (Ed.). Excavations at Tel Beth Shean 1989-1996, I. Israel Exploration Society and the Hebrew University, Jerusalem: 392-394.

Knappett, C., Kilikoglou, V., Steele, V., Stern, B. (2005) The circulation and consumption of Red Lustrous Wheelmade ware: petrographic, chemical and residue analysis. Anatolian Studies, 55, 25-59. DOI: 10.1017/S0066154600000648

Knight, A. C. (1918). The tallow chandlers' company: its origin and a sketch of its history. Journal of British Archaeology Association, 24, 173-216. DOI: 10.1080/00681288.1918.11894485

León-Camacho, M., Viera-Alcaide, I. Vicario, I. M. (2004). Acorn (Quercus spp.) fruit lipids: saponifiable and unsaponifiable fractions: a detailed study. Journal of the American Oil Chemists' Society, 81, 447-453. DOI: 10.1007/s11746-004-0921-8

Leskinen, H., Suomela, J. P., Kallio, H. (2007). Quantification of triacylglycerol regioisomers by different mass spectrometric and liquid chromatographic methods. Chemistry and Physics of Lipids, 149, 2361-2373. DOI: 10.1016/j.chemphyslip.2007.06.146

Lucquin, A., Gibbs, K., Uchiyama, J., Saul, H., Ajimoto, M., Eley, Y., Craig, O. E. (2016). Ancient lipids document continuity in the use of early hunter-gatherer pottery through 9,000 years of Japanese prehistory. Proceedings of the National Academy of Sciences of the United States of America, 113, 3991-3996. DOI: 10.1073/pnas.1522908113

Maigro, Y. (2003). Ivory, bone and antler tools production systems at Chalain 4 (Jura, France): late Neolithic site, $3^{\text {rd }}$ millennium. From hooves to horns, from mollusc to mammoth-manufacture and of bone artefacts from prehistoric times to the present. Proceedings of the $4^{\text {th }}$ Meeting of the ICAZ WBRG at Tallinn, 113-126.

Matlova, V., Salque, M. R., Pavlu, I., Kyselka, J., Sedlarova, I., Filip, V., Evershed, R. P. (2017). Defining pottery use and animal management at the Neolithic site of Bylany (Czech Republic). Journal of Archaeological Science: Reports, 17, 262-274. DOI: 10.1016/j.jasrep.2017.05.028

Mirabaud S., Regert M. (2016). Le contenu des céramiques du site néolithique de Clair- vaux XIV. In Pétrequin, P., Pétrequin, A.-M., dir, Clairvaux, le "Néolithique Moyen Bourguignon”. Besançon, Presses universitaires de Franche-Comté, CRAVA, vol 2.

Mirabaud, S., Rolando, C., Regert, M. (2007). Molecular criteria for discriminating adipose fat and milk from different species by NanoESl MS and MS/MS of their triacylglycerols: Application to archaeological remains. Analytical Chemistry, 79, 6182-6192. DOI: 10.1021/ac070594p

Morris, S. (2013). From clay to milk in Mediterranean prehistory: tracking a special vessel. Annual Review of the Cotsen Institute of Archaeology, 70-79.

Mottram, H. R., Dudd, S. N., Lawrence, G. J., Stott, A. W., Evershed, R. P. (1999). New chromatographic, mass spectrometric and stable isotope approaches to the classification of degraded animal fats preserved in archaeological pottery. Journal of Chromatography A, 833, 209-221. DOI: 10.1016/S0021-9673(98)01041-3

Mukherjee, A., Gibson, A., Evershed, R. (2008). Trends in pig product processing at British Neolithic Grooved Ware sites traced through organic residues in potsherds. Journal of Archaeological Science, 35, 2059-2073. DOI: 10.1017/j.jas.2008.01.010

Mukherjee, A. J., Berstan, R., Copley, M. S., Gibson, A. M., Evershed, R. P. (2007). Compound-specific stable carbon isotopic detection of pig product processing in British Late Neolithic pottery. Antiquity, 81, 743-754. DOI: 10.1017/S0003598X00095703

Namdar, D., Neumann, R., Goren, Y., Weiner, S. (2009). The contents of unusual cone-shaped vessels (cornets) from the Chalcolithic of the southern Levant. Journal of Archaeological Science, 36, 629636. DOI: 10.1016/j.jas.2008.10.004

Navarrete, V., Colonese, A. C., Tornero, C., Antolín, F., Von Tersch, M., Eulàlia Subirà, M., Saña, M. (2017). Feeding Management Strategies among the Early Neolithic Pigs in the NE of the Iberian Peninsula. International Journal of Osteoarchaeology, 27(5), 839-852.

Navarrete, V., Bosch, J., Saña, M. (In press). Husbandry practices at the beginning of mining activity: new insights from the Neolithic mines at Gavà (Barcelona). Trabajos de Prehistoria. 
Ogrinc, N., Gams-Petrišic, M., Žigon, D., Gašparic, A. Ž., Budja, M. (2012). Pots and lipids: molecular and isotope evidence of food processing at Maharski prekop. Documenta Praehistorica, 39, 339-347. DOI: $10.4312 /$ dp.39.25

Oras, E., Higham, T. F. G., Cramp, L. J. E., Bull, I. D. (2017). Archaeological science and object biography: a Roman bronze lamp from Kavatsu bog (Estonia). Antiquity, 91, 124-138. DOI: 10.15184/aqy.2016.247

Outram, A. K., Stear, N. A., Bendrey, R., Olsen, S., Kasparov, A., Zaibert, V., Thorpe, N., Evershed, R. P. (2009). The Earliest Horse Harnessing and Milking. Science,

323: 1332-1335.

Pääkönen, M., Bläuer, A., Olsen, B., Evershed, R. P., Asplund, H. (2018). Contrasting patterns of prehistoric human diet and subsistence in northernmost Europe. Scientific Reports, 8, 1148. DOI:10.1038/s41598-018-19409-8

Papakosta, V., Oras, E., Isaksson, S. (2019). Early pottery use across the Baltic - A comparative lipid residue study on Ertebølle and Narva ceramics from coastal hunter-gatherer sites in southern Scandinavia, northern Germany and Estonia. Journal of Archaeological Science: Reports, 24: 142151. DOI: 10.1016/j.jasrep.2019.01.003

Portillo, A. M., Sanz, C. (2020). Fourth order method to compute the volume

of archaeological vessels using radial sections: Pintia pottery (Spain) as a case study. International Journal of Computer Mathematics. DOI: 10.1080/00207160.2020.1777405

Querré, G., Cassen, S., Vigier, E., Coppens, Y. (2020). La parure en callaïs du Néolithique européen. Archaeopress Archaeology, Oxford.

Querré, G., Cassen, S., Calligaro, T. (2015). Témoin d'échanges au Néolithique le long de la façade atlantique: la parure en variscite des tombes de l'ouest de la France. XXXVe rencontres internationales d'archéologie et d'histoire d'Antibes. Antibes, France, 403-418.

Rageot, M., Pêche-Quilichini, K., Py, V., Filippi, J. J., Fernandez, X., Regert, M. (2015). Exploitation of Beehive Products, Plant Exudates and Tars in Corsica during the Early Iron Age. Archaeometry, 58, 315-332. DOI: 10.1111/arcm.12172

Raven, A. M., van Bergen, P. F., Stott, A. W., Dudd, S. N., Evershed, R. P. (1997). Formation of longchain ketones in archaeological pottery vessels by pyrolysis of acyl lipids. Journal of Analytical and Applied Pyrolisis, 40-41, 267-285. DOI: 10.1016/S0165-2370(97)00036-3

Regert, M. (2011). Analytical strategies for discriminating archeological fatty substances from animal origin. Mass Spectrometry Reviews, 30, 177-220. DOI: 10.1002/mas.20271

Regert, M., Garnier, N., Decavallas, O., Cren-Olive, C., Rolando, C. (2003). Structural characterization of lipid constituents from natural substances preserved in archaeological environments. Measurement Science and Technology, 14, 1620-1630. DOI: 10.1088/0957-0233/14/9/313

Regert, M., Colinart, S., Degrand, L., Decavallas, O. (2001a). Chemical alteration and use of beeswax through time: Accelerated ageing tests and analysis of archaeological samples from various environmental contexts. Archaeometry, 43, 549-569. DOI: 10.1111/1475-4754.00036

Regert, M., Dudd, S., Van Bergen, P., Pétrequin, P., Evershed, R. (2001b). Investigations of solvent extractable lipids and insoluble polymeric components: organic residues in Neolithic ceramic vessels from Chalain (Jura, France). British Archaeological Reports (BAR) International Series, 939, 78-90.

Regert, M., Dudd, S. N., Pétrequin, P., Evershed, R. P. (1999). Fonction des céramiques et alimentation au Néolithique final sur les sites de Chalain [De nouvelles voies d'étude fondées sur l'analyse chimique des résidus organiques conservés dans les poteries]. Archeosciences, Revue d’Archéométrie, 23, 91100.

Rice, P. M. (2015). Pottery Analysis, Second Edition. The University of Chicago Press, Chicago.

Roffet-Salque, M., Dunne, J., Altoft, D. T., Casanova, E., Cramp, L. J. E., Smyth, J., Evershed, R. P. (2017). From the inside out: Upscaling organic residue analyses of archaeological ceramics. Journal of Archaeological Science: Reports, 16, 627-640. DOI: 10.1016/j.jasrep.2016.04.005

Roffet-Salque, M., Regert, M., Evershed, R. P., Outram, A. K., Cramp, L. J., Decavallas, O., Dunne, J., Gerbault, P., Milo, S., Mirabaud, S., Pääkkönen, M., Smyth, J., Šoberl, L., Whelton, H. L., AldayRuiz, A., Asplund, H., Bartkowiak, M., Bayer-Niemeier, E., Belhouch, L., Bernardini, F., Budja, M., Cooney, G., Cubas, M., Danaher, E. M., Diniz, M., Domboróczki, L., Fabbri, C., González-Urquijo, J. E., Guilaine, J., Hachi, S., Hartwell, B. N., Hofmann, D., Hohle, I., Ibañez, J. J., Karul, N., Kherbouche, F., Kiely, J., Kotsakis, K., Lu,h, F., Mallory, J. P., Manen, C., Marciniak, A., Maurice- 
Chabard, B., Mc Gonigle, M. A., Mulazzani, S., Özdokan, M., Perik, O. S., Perik, S. R., Petrasch, J., Pétrequin, A.-M., Pétrequin, P., Poensgen, U., Pollard, C. J., Poplin, F., Radi, G., Stadler, P., Stäuble, H., Tasik, N., Urem-Kotsou, D., Walsh, F., Whittle, A., Wolfram, S., Zapata-Peña, L., Zoughlami, J. (2015). Widespread exploitation of the honeybee by early Neolithic farmers. Nature, 527, 226230. DOI: $10.1038 /$ nature 15757

Roffet-Salque, M., Bogucki, P. I., Pyzel, J., Sobkowiak-Tabaka, I., Grygiel, R., Szmyt, M., Evershed, R. P. (2013). Earliest evidence for cheese making in the sixth millennium BC in northern Europe. Nature, 493. DOI: 10.1038/nature11698

Roffet-Salque, M., Radi, G., Tagliacozzo, A., Pino, B., Wolfram, S., Hohle, I., Stäuble, H., Whittle, A., Hofmann, D., Pechtl, J., Schade-Lindig, S., Eisenhauer, U., Evershed, R. P. (2012). New insights into the Early Neolithic economy and management of animals in Southern and Central Europe revealed using lipid residue analyses of pottery vessels. Anthropozoologica, 47, 45-62. DOI : 10.5252/az2012n2a4

Romanus, K., Poblome, J., Verbeke, K., Luypaerts, A., Jacobs, P., De Vos, D., Waelkens, M. (2007). An evaluation of analytical and interpretative methodologies for the extraction and identification of lipids associated with pottery sherds from the site of Sagalassos, Turkey. Archaeometry, 49, 729747. DOI: $10.1111 /$ j.1475-4754.2007.00332.x

Ros, M.T. (1994). Estudi de les restes botàniques: Anàlisi antracològica de les mines 68 i 70. In: Bosch, J., Estrada,

A. (coord.) El Neolític Postcardial a les Mines Prehistòriques de Gavà (Baix Llobregat). Rubricatum. Revista del Museu de Gavà, 0, Gavà: Museu de Gavà, 214-218.

Roumpou, M., Heron, C., Andreou, S., Kotsakis, K. (2003). Organic Residues in Storage Vessels from the Toumba Thessalonikis. Prehistoric Pottery: People, Pattern and Purpose, 1156, 189-200.

Sánchez, A., Cerdeño, M.L. (2014). Propuesta metodológica para el estudio volumétrico de cerámica arqueológica a través de programas free-software de edición 3D: el caso de la necrópolis celtibérica del área meseteña. Virtual Archaeology Review, 5: 20-33. DOI: 10.4995/var.2014.4173

Saña, M. (1994). Gestió i explotació de recursos faunístics (macrofauna). In: Bosch, J., Estrada, A. (coord) Rubricatum. Revista del Museu de Gavà: el Neolític Postcardial a les Mines Prehistòriques de Gavà (Baix Llobregat), 0, Gavà: Museu de Gavà, 179 - 185.

Senior, L.M., Birnie, D.P. (1995). Accurately estimating vessel volume from profile illustrations. American Antiquity, 60: 319-334. DOI: 10.2307/282143

Shillito, L. M. (2019). Building Stonehenge? An alternative interpretation of lipid residues in Neolithic Grooved Ware from Durrignton Walls. Antiquity, 93, 1052-1060. DOI: 10.15184/aqy.2019.62

Šoberl, L., Horvat, M., Zibrat, A., Sraka, M., Evershed, R., Budja, M. (2014). Neolithic and Eneolithic activities inferred from organic residue analysis of pottery from Mala Triglavca, Moverna vas and Ajdovska jama, Slovenia. Documenta Praehistorica, 41, 149-179. DOI: 10.4312/dp.41.9

SopenaVicién, M.C. (2006). La investigación arqueológica a partir del dibujo informatizado de cerámica. SALDVIE, 6: 13-27.

Spiteri, C. (2012). Pottery use at the transition to agriculture in the western Mediterranean. Evidence from biomolecular and isotopic characterisation of organic residues in Impressed/Cardial Ware vessels. PhD thesis, University of York.

Spiteri, C., Gillis, R. E., Salque, M. R., Castells, L., Guilaine, J., Manen, C., Muntoni, I. M., Saña, M., Urem-Kotsou, D., Whelton, H. L., Craig, O. E., Vigne, J. D., Evershed, R. P. (2016). Regional asynchronicity in lactic production and processing in early farming communities of the northern Mediterranean. Proceedings of the National Academy of Sciences of the United States of America, 113, 13594-13599. DOI: 10.1073/pnas.1607810113

Stacey R. J. (2009). Organic residues: origins, analysis and scope - an overview for the archaeological ceramicist. The Old Potter's Almanack, 14, 1-7.

Steele, V. J., Stern, B., Stott, A. W. (2010). Olive oil or lard?: Distinguishing plant oils from animal fats in the archeological record of the Eastern Mediterranean using gas chromatography/ combustion/isotope ratio mass spectrometry. Rapid Communications in Mass Spectrometry, 24, 3478-3484. DOI: $10.1002 / \mathrm{rcm} .4790$

Tarifa-Mateo, N. (2019). Pottery use on the Mediterranean coast of the Iberian Peninsula (5400-3900 cal BC). PhD Thesis, Universitat Autònoma de Barcelona. 
Tarifa-Mateo, N., Clop-García, X., Rosell-Melé, A., Camalich-Massieu, M. D., Comes-Bordas, P., Martín-Socas, D., Rodríguez-Santos, F. J. (2019). New insights from Neolithic pottery analyses reveal subsistence practices and pottery use in early farmers from Cueva de El Toro (Málaga, Spain). Archaeological and Anthropological Sciences, 11, 5199-5211. DOI: 10.1007/s12520019-00874-9

Velasco, C., Celdrán, E. (2019). Towards an optimal method for estimating vessel capacity in large samples. Journal of Archaeological Science: Reports, 27: 1-12. DOI: 10.1016/j.jasrep.2019.101966

Vieugué, J., Mirabaud, S., Regert, M. (2008). Contribution méthodologique à l'analyse fonctionnelle des céramiques d'un habitat néolithique : l'exemple de Kovačevo (6200- 5500 av. J.-C., Bulgarie). ArchéoSciences, 32, 99-113. DOI: 10.4000/archeosciences.1010

Villalba, M. J., Bañolas, L., Arenas, J., Alonso, M. (1986). Les Mines Neolítiques de Can Tintorer: Gava. Excavacions 1878-80. Generalitat de Catalunya, Barcelona.

Whelton, H. L., Roffet-Salque, M., Kotsakis, K., Urem-Kotsou, D., Evershed, R. P. (2018). Strong bias towards carcass product processing at Neolithic settlements in northern Greece revealed through absorbed lipid residues of archaeological pottery. Quaternary International, 496, 127- 139. DOI: 10.1016/j.quaint.2017.12.018

Zapassky, E., Finkelstein, I., Benenson, I. (2006). Ancient standards of volume: Negevite Iron Age pottery (Israel) as a case study in 3D modelling. Journal of Archaeological Science, 33: 17341743. DOI: $10.1016 /$ j.jas.2006.03.005 


\begin{tabular}{|lccccc}
\hline ID Lab & ID Sample & Mine & Context & Volume (L) & Selected part \\
\hline \hline MIG07 & NI & 41 & Mining exploitation & - & Base \\
MIG08 & NI & 89 & Mining exploitation & - & Rim \\
MIG09 & $390-33$ & 7 & Mining exploitation & 0.5 & Rim \\
MIG10 & 1224 & 41 & Mining exploitation & 0.2 & Rim \\
MIG11 & NI & 83 & Funerary & - & Base \\
MIG12 & $408-1-$ NII-SF & 6 & Mining exploitation & 0.5 & Base \\
MIG13 & 11 & 68 & Mining exploitation & - & Rim \\
MIG14 & $408-2$ & 6 & Mining exploitation & 0.4 & Base \\
MIG16 & $418-16$ & 8 & Funerary & 0.45 & Base \\
MIG17 & CT41164 & 85 & Mining exploitation & 1.21 & Base \\
MIG18 & NI & 84 & Funerary & 0.9 & Base \\
MIG19 & 214 & 84 & Funerary & 0.7 & Rim \\
MIG20 & 1 & 84 & Funerary & 0.5 & Rim \\
MIG21 & 2 & 84 & Mining exploitation & 0.3 & Base \\
MIG22 & 458 & 90 & Mining exploitation & - & Rim \\
MIG23 & 14 & 90 & Mining exploitation & - & Base \\
MIG24 & 3 & 84 & Mining exploitation & - & Rim \\
MIG25 & $1090-26-N I$ & 41 & Mining exploitation & 0.3 & Base \\
MIG26 & $91-2004$ & 68 & Mining exploitation & - & Rim \\
MIG27 & $68-19$ & 68 & Mining exploitation & - & Rim \\
MIG28 & $19-2004$ & 68 & Mining exploitation & - & Base \\
\hline
\end{tabular}




\section{Shape description}

Potsherd

Potsherd

Ovoid morphology, incoming walls with two handles

Hemispherical form with divergent walls and one handle

Base reuse as a plate

Hemispherical form with flat base and one horizontal punch

Potsherd - Rim with handles

Hemispherical form with flat base and one horizontal punch

Hemispherical form with divergent walls and one handle

Hemispherical bowl with four handles

Boca quadratta

Ellipsoidal form with narrow neck and four handles

Hemispherical form with narrow neck and punches

Hemispherical form with divergent walls and one handle

Potsherd

Potsherd

Potsherd

Hemispherical form with divergent walls and two double punch handles

Potsherd

Potsherd

Potsherd 


\begin{tabular}{|c|c|c|c|c|c|c|c|c|}
\hline \multirow[b]{2}{*}{ Samples } & \multirow[b]{2}{*}{ ID } & \multirow[b]{2}{*}{$\operatorname{TLE}\left(\mu \mathrm{g} \mathrm{g}^{-1}\right)$} & \multirow[b]{2}{*}{ PS ratio } & \multirow[b]{2}{*}{ Lipids detected } & \multicolumn{2}{|c|}{$\delta^{13} \mathrm{C}$} & \multirow[b]{2}{*}{$\Delta 13 C$} & \multirow[b]{2}{*}{ Predominant commodity type } \\
\hline & & & & & $\begin{array}{c}\text { C16:0 } \\
\pm 0,3(\% \circ) \\
\end{array}$ & $\begin{array}{c}\text { C18:0 } \\
\pm 0,3(\%) \\
\end{array}$ & & \\
\hline MIG09 & M7-390-33 & 103 & 1,96 & FA $(16>18), M A G, D A G$. TAG & $-25,1$ & $-22,99$ & 2,11 & Non-ruminant adipose fat \\
\hline MIG10 & M41-1224 & 53 & 1,18 & FA $(16>18)$ & $-22,94$ & $-23,27$ & $-0,33$ & Mixture of animal fats \\
\hline MIG11 & M83 & 224 & 1,64 & FA $(16>18,18: 1)$; Sterols: $\beta$-sitosterol & $-27,2$ & $-26,83$ & 0,37 & Non-ruminant adipose fat and plants \\
\hline MIG12 & M6-408-1-NII-SF & 116 & 1,66 & FA $(16>18)$, MAG, DAG & $-28,93$ & $-31,17$ & $-2,24$ & Ruminant adipose fat \\
\hline MIG13 & M68-11 & 202 & 1,03 & $\begin{array}{c}\text { FA (16>18, } 18: 1,20) \text {; Sterols: cholesterol, } \\
\text { stigmasterol, } \beta \text {-sitosterol }\end{array}$ & $-25,11$ & $-25,27$ & $-0,16$ & Mixture of animal fats and plants \\
\hline MIG14 & M6-408-2 & 104 & 1,09 & FA $(14,16>18)$, MAG, DAG, TAG; Alkanes & $-24,5$ & $-23,42$ & 1,08 & Non-ruminant adipose fat \\
\hline MIG16 & M8-418-16 & 225 & 0,99 & $\begin{array}{c}\text { FA (14, 16>18, 20), MAG, DAG, TAG; Sterols: } \\
\text { stigmasterol, } \beta \text {-sitosterol }\end{array}$ & $-25,57$ & $-25,57$ & 0 & Mixture of animal fats and plants \\
\hline MIG17 & M85-CT41164 & 89 & 1,07 & FA $(16>18)$ & $-26,91$ & $-29,23$ & $-2,32$ & Ruminant adipose fat \\
\hline MIG18 & M84 & 109 & $\mathrm{x}$ & Wax esters (42-50); Alcohols (28-32) & $\mathrm{x}$ & $\mathrm{x}$ & $\mathrm{x}$ & Beeswax \\
\hline MIG19 & M84- 214 & 232 & 0,96 & FA $(16<18)$ & $-27,4$ & $-29,88$ & $-2,48$ & Ruminant adipose fat \\
\hline MIG20 & M84-1 & 187 & 1,17 & FA $(16>18)$ & $-24,97$ & $-24,6$ & 0,37 & Non-ruminant adipose fat \\
\hline MIG21 & M90 & 408 & 4,69 & FA $(16>18)$, MAG, DAG. TAG; Sterols: $\beta$-sitosterol & $-25,53$ & $-25,67$ & $-0,14$ & Mixture of animal fats and plants \\
\hline MIG22 & M90 & 40 & 0,87 & FA $(16<18)$, MAG, DAG. TAG; Sterols: $\beta$-sitosterol & $-24,85$ & $-25,43$ & $-0,58$ & Non-ruminant adipose fat and plants \\
\hline MIG25 & M41-1090-26-NI & 137 & 0,37 & $\begin{array}{l}\text { FA }(16<18), \text { MAG, DAG; Wax esters }(40-52) ; \\
\text { Alcohols }(26-32) \text {; Sterols: } \beta \text {-sitosterol }\end{array}$ & $\mathrm{x}$ & $\mathrm{x}$ & $\mathrm{x}$ & Beeswax and animal fat \\
\hline MIG28 & M68-91-2004 & 113 & 1,01 & FA $(16>18)$ & $-27,5$ & $-27,54$ & $-0,04$ & Ruminant adipose fat \\
\hline
\end{tabular}

